\title{
The brown parmelioid lichen species in Greenland
}

\author{
Theodore L. Esslinger ${ }^{1}$, Eric Steen Hansen ${ }^{2} \&$ Steven D. Leavitt ${ }^{3}$ \\ ${ }^{1}$ Department of Biological Sciences, North Dakota State University, Fargo, North Dakota 58108 \\ E-mail: ted.esslinger@ndsu.edu \\ ${ }^{2}$ Natural History Museum of Denmark, University of Copenhagen, Herbarium, Botanical Garden, \\ Øster Farimagsgade 2 C, DK-1123 Copenhagen, Denmark \\ E-mail: erich@snm.ku.dk \\ ${ }^{3}$ Department of Science and Education, The Field Museum, 1400 S. Lake Shore Drive, Chicago, IL 60605-2496 \\ E-mail: sleavitt@fieldmuseum.org
}

\begin{abstract}
Sixteen species of brown parmelioids are reported from Greenland, including one species of Cetrariella, three species of Melanelia, two species of Melanelixia, six species of Melanohalea, and four species of Montanelia. Descriptions and a key are provided.
\end{abstract}

\section{INTRODUCTION}

In recent years, most of the brown parmelioid lichen species had been included in the genus Melanelia (Esslinger, 1978, 2002). Within the last decade, data from molecular phylogenetic studies have shown this genus to be polyphyletic and several new genera have been segregated from it, including Melanohalea and Melanelixia (Blanco et al., 2004) and most recently Montanelia (Divakar et al., 2012). The evolution and phylogeny of Melanohalea and Melanelixia have received considerable further attention recently (Leavitt et al., 2012a, 2012b, 2013), in studies using large numbers of specimens and including most species. Recently, we completed a DNA barcoding study of brown parmelioid taxa, with emphasis on the species occurring in Greenland (Leavitt et al., 2014), which helped clarify the taxonomic delimitations for some species and was the impetus for the present study.

The literature dealing with Greenland brown parmelioids comprises ca. 80 titles. Fries (1860) and Branth \& Grønlund (1888) were among the first to mention collections of brown parmeloids from Greenland. In these pioneering works, all species belonging to this group of lichens are referred to the genus Parmelia. Very little, often imprecise, information about the occurrence and distribution of the taxa is given, but this is understandable, since only a comparatively small part of the extensive area of Greenland was known lichenologically at that time. Some decades passed before proper discussions of taxonomic and chemical problems concerning the Greenland brown parmeloids would appear (Lynge \& Scholander, 1932; Lynge, 1937; Dahl et al., 1937; Dahl, 1950). In these works some brown parmelioids were referred to the genus Cetraria. K. Hansen (1971) gave detailed descriptions of the ecology and distribution of different brown parmelioids in South West Greenland, while Thomson (1984) and E. S. Hansen (1982, 1995a) provided a detailed survey of the ecology and distribution of these lichens based on all Greenland collections available at the time. Since then the last mentioned author has collected lichens, including brown parmelioids, in many poorly known and lichenologically unknown parts of Greenland and published them in numerous papers, for example, Hansen (2009, 2011). He has undertaken forty lichen collecting trips to almost all parts of Greenland since 1969, and brown parmelioids are generally well represented in his collections.

The key and descriptions provided here should prove useful for identifications in other northern parts of the Northern Hemisphere. For instance, the Greenland species of Melanelia and Montanelia are shared in toto by the Nordic flora as well as that of northern North America (Canada and Alaska). For Melanohalea, six of the seven species in the Nordic flora also occur in Greenland, although for North America that ratio is only six of twelve species. Melanelixia occurs only incidentally in Greenland, with only two introduced species. 


\section{MATERIAL AND METHODS}

More than 1200 specimens of brown parmelioids housed at herbarium $\mathrm{C}$ were examined for this study, primarily from five genera: Melanelia, $\mathrm{Mel}$ anelixia, Melanohalea, Montanelia and Cetrariella. Descriptions are based on all specimens examined by the authors, not just the Greenland materials, although the specimens examined numbers quoted for each taxon include only Greenland specimens. The secondary chemistry of the species in question is fairly well known already, but a representative selection of the Greenland specimens was subjected to thinlayer chromatography (TLC) for this work, using modifications of the standardized methods first described by Culberson and Kristinsson (1970) and Culberson (1972, 1974). For species with more than one substance, the chemical reports below use symbols $(+++,++,+,-)$ to represent their usual relative proportions. In cases where relatively recent collections from Greenland were available, those specimens were included in the DNA barcoding study (Leavitt et al., 2014).

\section{RESULTS}

\section{Key to the species of the brown parmelioid genera in Greenland}

1a. Thallus with asexual propagules, either soredia and/or isidia or lobules

2a. Thallus with soredia (sometimes accompanied by small, fine isidia as well)

3a. Medulla C+ rose or red (sample freshly exposed medulla in younger thallus parts)

4a. With distinct laminal pseudocyphellae; thallus saxicolous; soredia granular to isidioid, but without true isidia.

Montanelia tominii

4b. Without distinct laminal pseudocyphellae (faint flecks at most), thallus usually corticolous or lignicolous; soredia powdery to granular, often with fine isidia developing within and between soralia..... Melanelixia subaurifera

3b. Medulla C-

5a. Soralia laminal and submarginal, punctiform to capitate or short stipitate, sometimes becoming more or less confluent in older thallus parts; lobes often shiny, bearing distinct to very obscure submarginal pseudocyphellae....

Montanelia disjuncta

5b. Soralia largely terminal on the primary lobes and/or on short, often more or less erect, lateral branches; lobes usually dull to slightly shiny, without pseudocyphellae

Montanelia sorediata

2b. Thallus lacking soredia, but with true, more or less upright isidia, or with numerous small, imbricate lobules, which may cover much of the upper surface

6a. Medulla $\mathrm{C}+$ rose or red

7a. Thallus with isidia $0.2-1 \mathrm{~mm}$ long and up to $0.1 \mathrm{~mm}$ in diameter, often branched; soredia never present (occasionally broken isidia and erosion may be confused); with lecanoric and 5-methoxylecanoric acid, often with scattered anthraquinone pigment (skyrin) visible on lower surface medulla exposed by wounding ................................. Melanelixia glabratula

7b. Thallus with isidia very fine, $0.1-0.4 \mathrm{~mm}$ long and up to $0.06 \mathrm{~mm}$ in diameter, rarely branched, sparse to abundant soredia also usually present; with only lecanoric acid

Melanelixia subaurifera

6b. Medulla C-

8a. Thallus centrally with numerous, short to elongate, prostrate, imbricate lobules ('panniform'), which arise as isidioid papillae near the periphery......

$8 \mathrm{~b}$. Thallus with more or less upright isidia, these scattered or rather dense but not imbricate

9a. Isidia spherical when young, becoming compressed-clavate or spatulate, sometimes bifurcate at the end but rarely truly branched, usually appearing distinctly inflated 
9b. Isidia more or less cylindrical, not compressed, only occasionally looking slightly inflated, often somewhat branched

10a. Isidia arising near the lobe ends as small, conical to hemispherical papillae with obscure to distinctive pseudocyphellae at the tip, maturing inward into cylindrical isidia, often with side branches toward the end which are much smaller in diameter than the isidia; in Greenland, saxicolous, rarely corticolous

Melanohalea elegantula

10b. Isidia arising on lobes and inward as small, spherical to hemispherical papillae which lack pseudocyphellae, maturing into irregular, simple or sparsely branched isidia, the branches similar in diameter to the main isidium; saxicolous

Melanohalea infumata

1b. Thallus without distinctive asexual propagules, occasionally irregularly lobulate, usually fertile

11a. Thalli corticolous or lignicolous, usually some shade of olive-brown, pseudocyphellae rather inconspicuous or on the ends of evenly scattered papillae

12a. Thalli with rather evenly scattered and regular papillae on the upper surface, the papillae with distinct pseudocyphellae on the end; medulla always PD-....

Melanohalea exasperata

12b. Thalli smooth to rugose or irregularly papillate, pseudocyphellae absent or not on tips of regularly scattered papillae; medulla usually PD+red-orange (rarely PD-)

13a. Apothecia mostly on central thallus regions, up to $9 \mathrm{~mm}$ in diameter, the margin usually pseudocyphellate, becoming distinctly crenate or tuberculate and the amphithecium surface often becoming strongly rugose-foveolate; subhymenial tissue 30-80 $\mu \mathrm{m}$ thick

Melanohalea olivacea

13b. Apothecia often present on peripheral lobes as well as inward, up to $3(-5)$ $\mathrm{mm}$ in diameter, the margin entire or only weakly crenate and pseudocyphellate and the amphithecium surface remaining mostly smooth; subhymenial tissue usually 8-35 $\mathrm{mm}$ thick

Melanohalea septentrionalis

11b. Thalli usually saxicolous (rare on soil/detritus or very infrequent on bark or wood), often a darker brown; pseudocyphellae usually conspicuous, occurring on the lobe margins, or on the upper surface of the lobes (flush or slightly pitted)

14a. Lower surface black, only occasionally somewhat paler on the lobe ends but usually only close to the tips

15a. Pseudocyphellae laminal; lobes usually flat to somewhat convex, occasionally weakly concave, not rarely with upright, terete lobes developing; medulla $\mathrm{PD}+$ red-orange or $\mathrm{PD}-, \mathrm{K}$ - to $\mathrm{K}+$ dingy orange (fumarprotocetraric acid, or no substances)

Melanelia stygia

15b. Pseudocyphellae marginal; lobes usually flat to concave or even channeled, rarely convex; medulla $\mathrm{PD}-$ to $\mathrm{PD}+$ yellow or slightly yellow-orange, $\mathrm{K}+$ pale yellow to yellow or yellow-orange (stictic acid \pm norstictic acid)

Melanelia hepatizon

14b. Lower surface pale tan to pale brown throughout, or, more often, darkening or even blackening in localized regions, either centrally or sometimes peripherally, but not predominantly black

16a. Thallus mostly appressed and adnate on rock, rhizines sparse but regularly present, mostly marginal or submarginal; pycnidia primarily marginal (but laminal sometimes present too), broad, usually only as tall as broad (a 1:1 ratio) but occasionally up to twice (or very rarely thrice) as tall as broad (2-3:1 ratio); conidia bifusiform, 4-7×1 $\mu \mathrm{m}$; no chemical substances detected 
16b. Thallus appressed to somewhat ascendant, rhizines very sparse and usually marginal, occasionally almost absent; pycnidia primarily marginal, narrow, varying from 1:1 up to 10:1 length to width ratio (at least a few of the longer ones usually present); conidia fusiform, 3-4.5 $\times$ ca. $1 \mu \mathrm{m}, \alpha$-collatolic acid talectoronic acid, or, no substances present.

Cetrariella commixta

\section{The Species}

Cetrariella commixta (Nyl.) A. Thell \& Kärnefelt (Fig. 1, Fig. 2)

Thallus foliose to subfruticose, appressed to somewhat ascendant, at times even rather strongly pulvinate, loosely adnate, up to 7 $(-10) \mathrm{cm}$ in diameter. Lobes $(0.2-) 0.5-1(-2)$ $\mathrm{mm}$ broad, flat to somewhat concave (not usually strongly channeled), usually elongate to linear-elongate, but occasionally with shorter, rounded lobes, loosely imbricate or entangled. Upper surface dark olive-brown to dark brown or black-brown, smooth to weakly foveolate on lobe ends, inward smooth to somewhat plicate or rugose, more or less weakly shiny throughout; without soredia or isidia; with rather frequent and conspicuous, marginal pseudocyphellae, these whitish to darkening, occasionally very elongate and almost continuous. Lower surface tan to pale brown on lobes, often blackening inward (sometimes only at the center, but in places as close as within ca. 1+ mm of lobe tip), often weakly to moderately foveolate, sparsely rhizinate (frequently almost absent), the few rhizines marginal, simple or sparsely furcate, concolorous with lower surface, to $1(-1.5) \mathrm{mm}$ long. Apothecia common, marginal or on short side lobes, usually clearly attached off center, concave to flat, up to $5 \mathrm{~mm}$ in diameter, the margin crenate and or warted, pseudocyphellate, also commonly bearing pycnidia; ascospores 8 , ellipsoid to subglobose, 7-10×4.5-6.5 $\mu \mathrm{m}$. Pycnidia common, nearly all marginal, emergent, becoming elongate, at times the majority may be only ca. 1:1 (as long as broad) but nearly always some (and often many) become distinctly elongate (becoming stalked) up to $2-5: 1$ or greater ratio of length to width (occasionally up to even ca. 8-10:1 or more), occasionally some of them branching and with $2-4$ heads (the actual pycnidia); conidia (2.5-)3-4.5×1-1+ $\mu \mathrm{m}$, fusiform (at times, a few are asymmetrically fusiform, appearing almost bottle shaped).

Thallus spot tests: cortex K-; medulla PD-, $\mathrm{K}-, \mathrm{C}-, \mathrm{KC}+$ rose to orangish or $\mathrm{KC}-$. Lichen substances: $\alpha$-collatolic $(+++)$, alectoronic $(++$ to -); or, most commonly (in Greenland), no substances detected.

Substrate \& ecology: on rocks, especially siliceous.
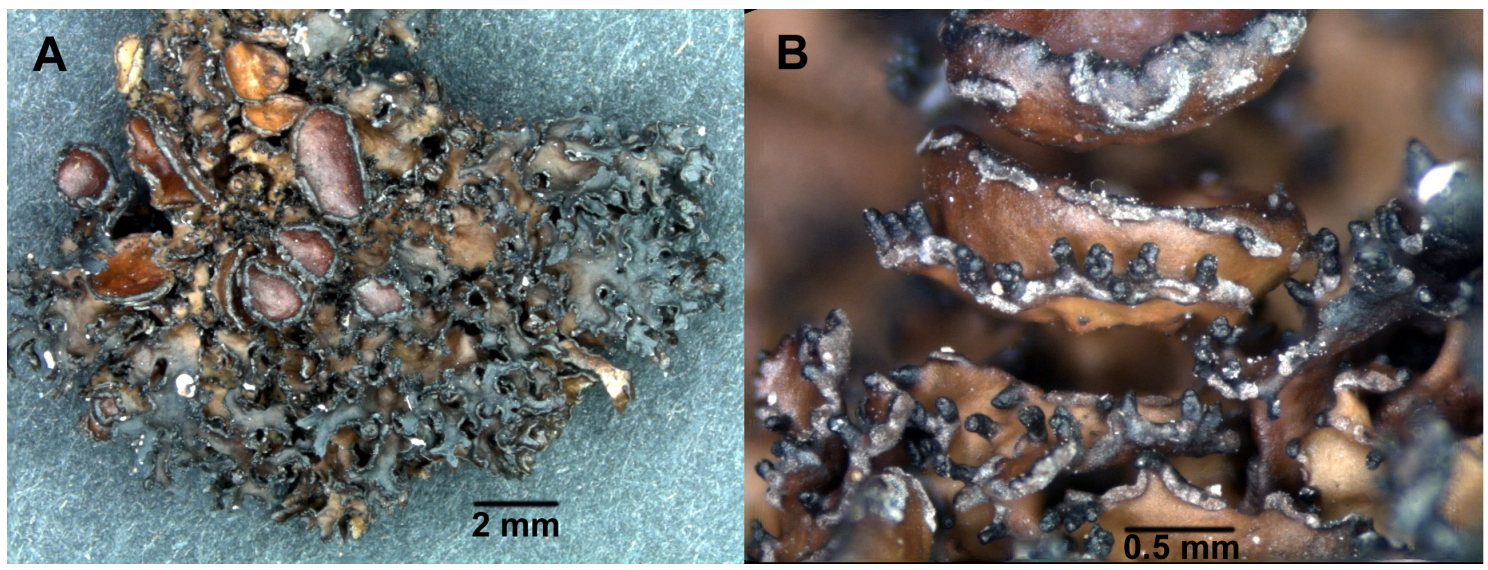

Fig. 1. Cetrariella commixta [Hansen 04.070 (C)]. A - Thallus with apothecia. B - Closeup showing elongate pycnidia on lobes (lower) and on the side of an apothecium (central). 


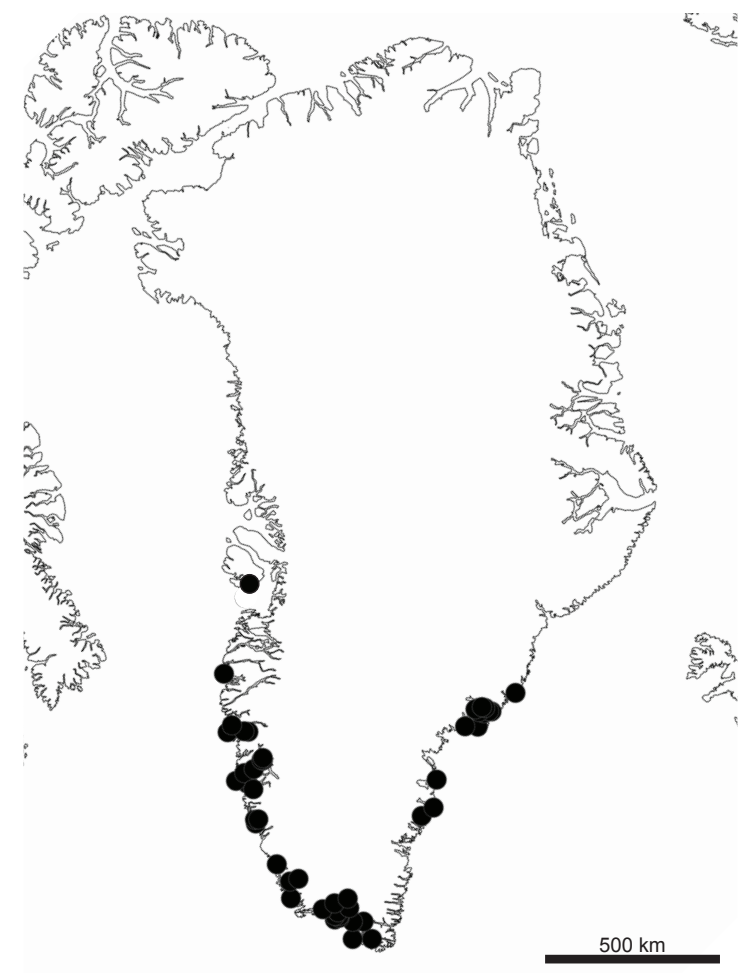

Fig. 2. Distribution of Cetrariella commixta in Greenland.

Distribution: common in South West Greenland and more scattered in South East Greenland (Dahl, 1950; Dahl et al., 1937; Hansen, 1971; Hansen, 1978a \& b); rare in Central West Greenland, where it occurs at Qeqertarsuaq.

Discussion: In habit, this taxon varies from more or less prostrate and appressed (like a Melanelia, a genus to which it has been assigned) to rather ascendant and loose, somewhat more like the other members of the genus Cetrariella, which tend to be more or less fruticose. When the typical, numerous and elongate pycnidia are present, this species is easily identified. Although specimens with only short pycnidia (with a ca. 1:1 or $2: 1$ length to width ratio) do occur, usually on sees at least a few pycnidia with a 3:1 (thrice as tall as broad) ratio or longer, and occasionally up to a ca.10:1 ratio or even longer. These structures are actually pycnidia occurring on the end of elongated marginal projections (Kärnefelt, 1979), the form in which pycnidia also occur in the other species of Cetrariella (Kärnefelt et al., 1993; Thell \& Kärnefelt, 2011). Usually, the entire length of the marginal projection appears black and carbonized like the main pycnidium wall itself. Occasionally, these projections bear more than a single pycnidium on the end (2-4 pycnidia on the ends is not uncommon).

All Greenland specimens with pycnidia were examined for conidia, and only fusiform conidia 3-4.5 $\mu \mathrm{m}$ long were observed. According to Thell et al. (2004) and Thell \& Kärnefelt (2011), the conidia of this species are sometimes sublageniform instead of fusiform. The first author (TLE) has studied specimens with such bottle-shaped conidia $(6-9 \times 1 \mu \mathrm{m})$ from western North America (Washington, British Columbia). Whether the specimens with these divergent conidial forms truly represent the same taxon seems questionable and should be tested using molecular techniques.

When present, the concentration of the lichen substances varies a great deal, with some specimens showing strong concentrations of both $\alpha$-collatolic acid and alectoronic acid by TLC, and others showing only $\alpha$-collatolic, with little or no alectoronic. Not all specimens were analyzed by TLC, but based on the spot tests, approximately $75 \%$ of Greenland specimens lack detectable quantities of these medullary substances. Some specimens without observable positive spot tests seem to exhibit a weak long wave UV + blue-white in parts of the medulla. However, most specimens with negative spot tests are also UV negative, and the concentration of phenolic medullary substances appears to vary all the way to nil. In the DNA barcoding study by Leavitt et al. (2014), two of the six Greenland specimens of C. commixta studied were chemistry nil (based on both TLC \& spot tests) and yet all six specimens formed a monophyletic group. If the distinctive pycnidia are overlooked or absent (rare), the KC- specimens of this species might be mistaken for Melanelia agnata, which has a similar pale lower surface, although it typically has more frequent rhizines and a somewhat more prostrate habit

When the phenolic substances are present, giving a $\mathrm{KC}+$ rose-orange reaction and $\mathrm{UV}++$ or UV+++ blue-white medulla, the identification of this species in Greenland is relatively straight forward. In the absence of these clues, however, one must rely on the habit (often loose and even somewhat ascendant), pale lower surface with very sparse (or even no) rhizines, presence of at 
least some elongate or stalked pycnidia (pycnidia on marginal projections, with a ratio up to 8 or 10 times as long as wide) which produce fusiform conidia $(2.5-4.5 \times 1-1+\mu \mathrm{m})$, and marginal pseudocyphellae. In North America (Alaska), the first author has encountered an undescribed species of Melanelia (with typical bifusiform conidia, 5-6×1 $\mu \mathrm{m}$ ) which produces $\alpha$-collatolic acid (but apparently not alectoronic acid) in the medulla and which has been confused with $C$. commixta.

Selected specimens examined (from a total of 95): Aappilattoq $\left(60^{\circ} 09^{\prime} \mathrm{N}, 44^{\circ} 17^{\prime} \mathrm{W}\right), 25$ Jul 2004, E. S. Hansen 04171 (C). Arsuk (61 $\left.{ }^{\circ} 11^{\prime} \mathrm{N}, 48^{\circ} 28^{\prime} \mathrm{W}\right), 10 \mathrm{Jul}$ 1993, E. S. Hansen 93464 (C). Sisimiut $\left(66^{\circ} 56^{\prime} N\right.$, $\left.53^{\circ} 40^{\prime} \mathrm{W}\right), 23$ Jun 1991, E. S. Hansen 91235 (C). Qeqertarsuaq $\left(69^{\circ} 15^{\prime} \mathrm{N}, 53^{\circ} 31^{\prime} \mathrm{W}\right)$, 6 Sep 1949, P. Gelting (C). Tuno (65 $\left.58^{\circ} \mathrm{N}, 36^{\circ} 49^{\prime} \mathrm{W}\right), 21$ Aug 2010, E. S. Hansen 10139 (C).

\section{Melanelia agnata (Nyl.) A. Thell (Fig. 3, Fig. 4)}

Thallus foliose, appressed to somewhat pulvinate, moderately to loosely adnate, up to $7-8 \mathrm{~cm}$ in diameter. Lobes $0.5-1 \mathrm{~mm}$ broad, almost flat to somewhat concave, usually elongate or linearelongate, contiguous to loosely imbricate. Upper surface occasionally tan-brown in part, but usually dark olive-brown to dark brown or blackbrown, smooth on lobe ends, inward smooth to somewhat plicate or rugose, dull throughout or more often shiny, especially at the periphery; without soredia or isidia, occasionally with scattered papillae which may elongate to form small dorsiventral lobules; usually with more or less conspicuous, marginal/submarginal pseudocyphellae, these whitish to darkening. Lower surface pale brown to brown at periphery, sometimes darkening somewhat inward or even blackening in oldest parts; more or less smooth to weakly rugose or weakly foveolate even at periphery, sparsely but regularly rhizinate, the rhizines primarily marginal or submarginal, simple or sparsely furcate, concolorous with lower surface, to $1 \mathrm{~mm}$ long. Apothecia infrequent (in Greenland), marginal, symmetrical to \pm acentric, concave to \pm flat, to $4-5 \mathrm{~mm}$ in diameter, the margin almost smooth to crenate or warted, sometimes lacerated, \pm pseudocyphellate; spores 8 , ellipsoid, 7.5-8×5-5.5 $\mu \mathrm{m}$ (only one specimen found with apoth). Pycnidia occasional (in Greenland), mostly marginal to submarginal, but occasionally with numerous laminal ones as well, emergent, length to width ratio usually $1-1.5: 1$ but occasionally up to 2-3:1; conidia 4-7×1 $\mu \mathrm{m}$, bifusiform.

Thallus spot tests: cortex K-; medulla PD-, K- , $\mathrm{C}-$, $\mathrm{KC}-$. Lichen substances: none detected.

Substrate \& ecology: grows on basaltic and, more frequently, on siliceous rocks, often together with Melanelia hepatizon and metal indicator species such as, e.g., Porpidia flavocaerulescens. M. agnata appears to be fairly common on syenites and other types of rocks belonging to the Ilimaussaq intrusion (Kvanefjeld) rich in comparatively rare elements such as uranium, thorium, beryllium and niobium (Ferguson, 1964; Hansen, 1978a). The species probably can be used as indicator for such rocks. It is also of

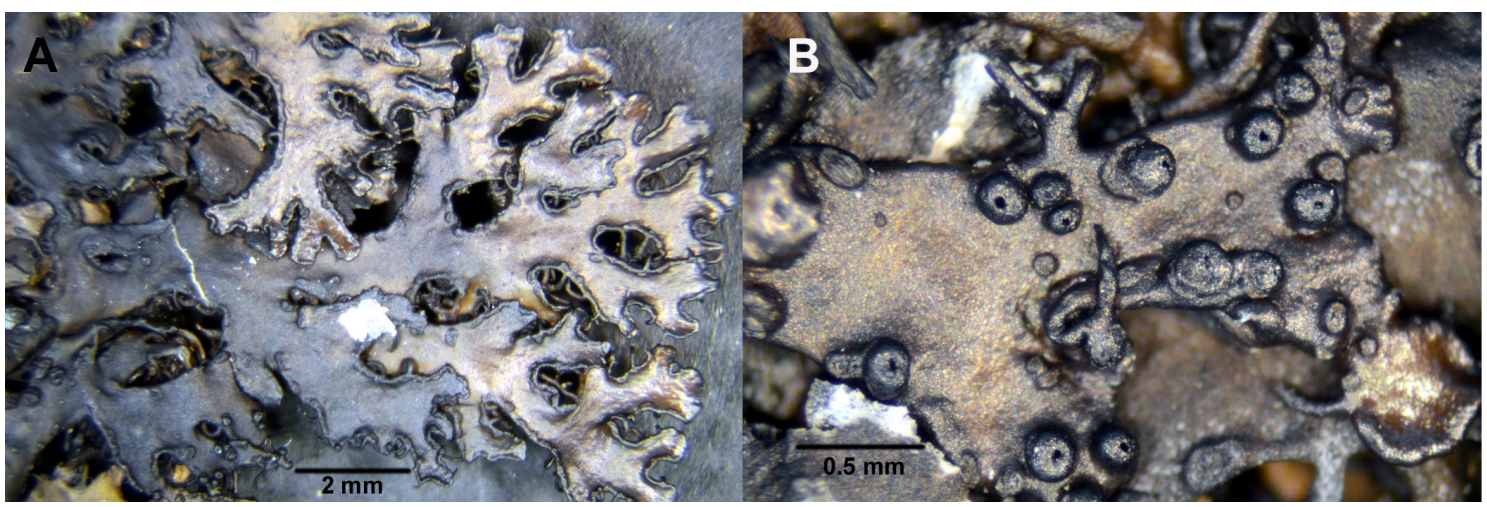

Fig. 3. Melanelia agnata [Gelting 10028 (C)]. A - Thalllus. B - Closeup of short, broad pycnidia on or near lobe edges. 
great interest that $M$. agnata is common on some nunataks in South West Greenland, for example, J. A. D Jensens nunatakker (Hansen, 2010).

Distribution: Widely distributed in Greenland. It is common in South West Greenland and occurs more scattered in Central West Greenland (Disko). M. agnata is known from a few localities in South East Greenland, e.g., Qingertuaq, Seraq and Nordre Aputiteeq, and Central East Greenland, e.g., Ittoqqortoormiit and Danmarkshavn. The species has also been collected at Gletscher Sø in North East Greenland (Alstrup et al., 2000) and has even been found in a few localities at the north coast of Greenland (Hansen, 2009)

Discussion: In general form, this species is much like $M$. hepatizon and exhibits a similar range of morphological variation. That species is usually easily distinguished from $M$. agnata

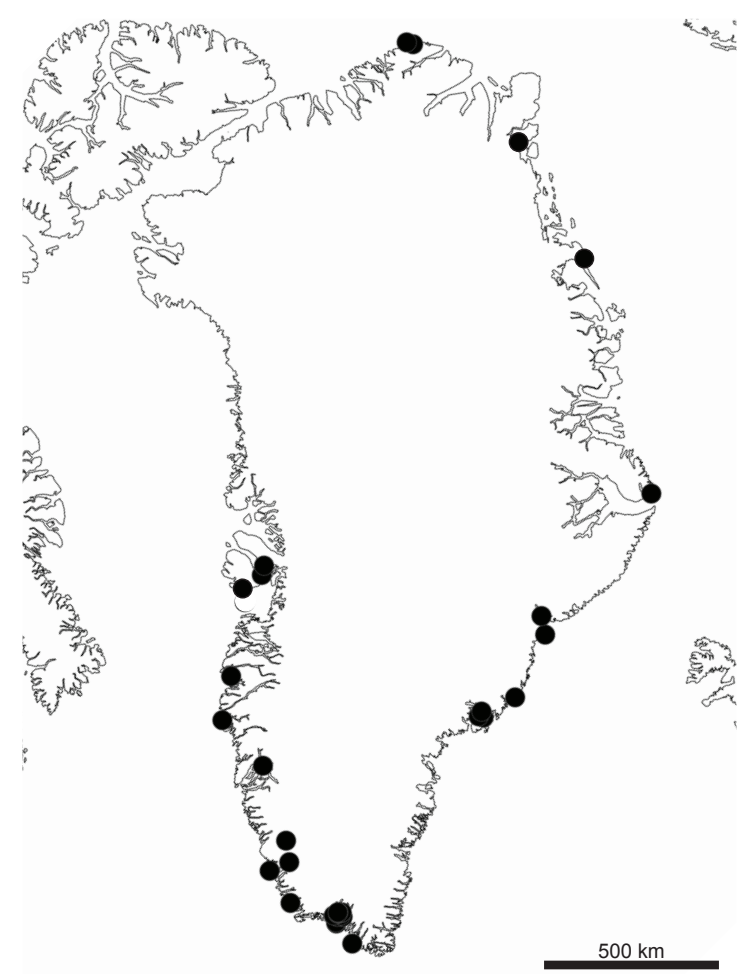

Fig. 4. Distribution of Melanelia agnata in Greenland. by its production of stictic acid ( \pm norstictic) and $\mathrm{K}+$ yellow to yellow-orange medulla, although very rarely $M$. hepatizon has a medullary reaction so weak that it can be hard to decipher. The lower surface of $M$. hepatizon is almost always uniformly black, whereas that of $M$. agnata is largely pale tan to brown, blackening only here and there, usually in the older parts.

Because of similar spot test reactions and the pale lower surface, $M$. agnata can be confused with the specimens of C. commixta lacking detectable phenolics. As long as pycnidia and conidia are present, the bifusiform conidia of $M$. agnata are easy to tell from the shorter, ellipsoid conidia of $C$. commixta. In the absence of pycnidia, the more prostrate habit and the sparse but regularly scattered rhizines on the lower surface will help distinguish $M$. agnata.

Selected specimens examined (from a total of 51): Kvanefjeld (6059'N, 455' W), alt. 545 m, 24 Jul 1978, $V$. Alstrup 243933k (C). J. A. D. Jensens nunatakker $\left(62^{\circ} 50^{\prime} \mathrm{N}, 48^{\circ} 55^{\prime} \mathrm{W}\right), 4$ Jul 2009, E. S. Hansen 09435 (C). Qíngertuaq $\left(66^{\circ} 06^{\prime} \mathrm{N}, 37^{\circ} 13^{\prime} \mathrm{W}\right)$, alt. $950 \mathrm{~m}, 4$ Aug 1970, E. S. Hansen 703901 (C). Gletscher Sø (7957'N, $\left.21^{\circ} 59^{\prime} \mathrm{W}\right)$, alt. $900 \mathrm{~m}, 20 \mathrm{Jul} 1995, \mathrm{~V}$. Alstrup \& F. Daniels 3409 (C). Constable Bugt $\left(83^{\circ} 34^{\prime} \mathrm{N}, 32^{\circ} 01^{\prime} \mathrm{W}\right)$, 13 Aug 2007, E. S. Hansen 07464 (C).

\section{Melanelia hepatizon (Ach.) A. Thell (Fig. 5)}

Thallus foliose, appressed to rather strongly pulvinate or somewhat panniform, moderately to loosely adnate, up to $15-16 \mathrm{~cm}$ in diameter. Lobes $0.5-1.5 \mathrm{~mm}$ broad, usually weakly to strongly concave and often with a conspicuous rim; somewhat elongate to shorter and more rounded-flabellate, contiguous to imbricate. Upper surface dark olive-brown to dark brown or black-brown, smooth at periphery, inward smooth to tuberculate or rugose, dull throughout or more often shiny, especially at the periphery; without soredia or isidia, occasionally with scattered marginal, narrow and \pm elongate lobules, usually in older parts; usually with numerous and conspicuous marginal pseudocyphellae, these whitish to darkening. Lower surface black, sometimes paler on the lobe ends, mostly smooth at the periphery, somewhat rugose or foveolate inward, moderately to sparsely rhizinate, the rhizines mostly marginal, simple or sparsely furcate, black, to $1 \mathrm{~mm}$ long. Apothecia common, marginal or submarginal, concave to flat, to $8 \mathrm{~mm}$ in diameter, the margin crenate and or warted, pseudocyphellate; spores 8, ellip- 
soid to subglobose, 7-10.5×4.5-6 $\mu \mathrm{m}$. Pycnidia common, mostly marginal/submarginal but also sometimes laminal in small clusters or larger groups, emergent, usually ca. as long as broad (1:1 to $1.5: 1$ [rarely up to $2: 1$ ]); conidia $4-5.5 \times 1+$ $\mu \mathrm{m}$, bifusiform.

Thallus spot tests: cortex $\mathrm{K}-$; medulla $\mathrm{PD}+$ pale yellow to golden-yellow, $\mathrm{K}+$ yellow to yelloworange, $\mathrm{C}-$. Lichen substances: stictic acid $(+++)$, norstictic acid ( - to + ), but see discussion below.

Substrate and ecology: grows on siliceous and basaltic rocks and infrequently (ca. 11 of 389) on wood or bark of, for example, Betula nana and Salix glauca.

Distribution: the most common brown parmelioid in Greenland, and widely distributed except for North West and North East Greenland, where it has a more scattered occurrence (Lynge \& Scholander, 1932; Dahl, 1950; Hansen, 1971; Hansen, 1978a \& b, 1995b, 2011); so far not found at the north coast of Greenland.

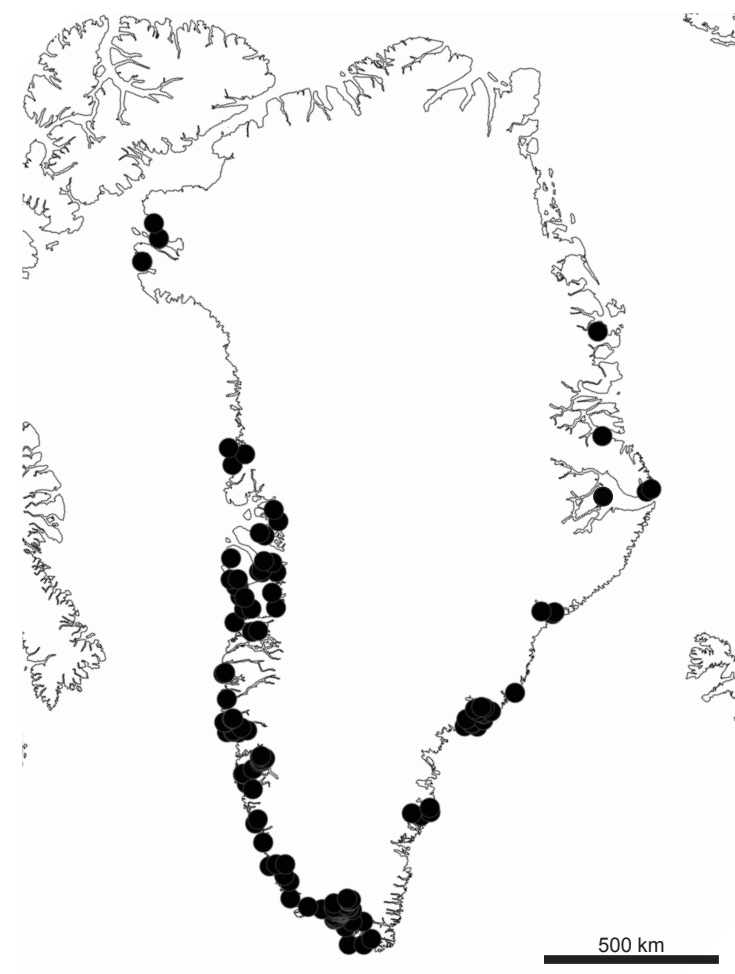

Fig. 5. Distribution of Melanelia hepatizon in Greenland.
Discussion: The characteristic and essentially constant chemistry makes this species relatively distinctive. Significant variation exists in the concentration of stictic acid in the medulla, however, resulting in medullary spot tests that range from $\mathrm{K}+$ very pale yellow to $\mathrm{K}+$ yellow-orange (with parallel variability in the $\mathrm{PD}$ reactions). Among the hundreds of specimens studied for this paper, only one was found (Alstrup 766222) in which the medullary spot tests were too weak to read with certainty, seemingly negative in most spots with only one spot which gave a very weak yellowish reaction. Otherwise, the specimen was relatively typical and it had the characteristic uniformly black lower surface, distinguishing it from $M$. agnata.

Melanelia stygia shares the black lower surface with $M$. hepatizon, but has pseudocyphellae that are not restricted to the lobe margins, and the spot tests are usually distinctly different, being either $\mathrm{PD}-$ and $\mathrm{K}$ - or $\mathrm{PD}+$ red-orange and $\mathrm{K}$ dingy to $\mathrm{K}+$ dingy orange.

Specimens with the panniform morphotype (e.g. Hansen 10B.014) appear very different from the more typical form, having numerous, small and narrow $( \pm 0.5)$ lobes tightly overlapping. The lobes are only weakly concave and without a conspicuous rim, and the pseudocyphellae are often sparse and rather inconspicuous.

Selected specimens examined (from a total of 389): Iterdlaq $\left(60^{\circ} 56^{\prime} \mathrm{N}, 45^{\circ} 16^{\prime} \mathrm{W}\right)$, alt. $500 \mathrm{~m}, 30 \mathrm{Jul} 1962$, K. Hansen 282 (C). Siorapaluk $\left(77^{\circ} 47^{\prime} \mathrm{N}\right.$., $\left.70^{\circ} 29^{\prime} \mathrm{W}\right)$, 24 Jul 2009, E. S. Hansen 09164 (C). Qingertuaq $\left(66^{\circ} 06^{\prime} \mathrm{N}, 37^{\circ} 13^{\prime} \mathrm{W}\right)$, alt. $600 \mathrm{~m}, 1$ Aug 1970, E. S. Hansen 701816 (C). Kap Hope $\left(70^{\circ} 28^{\prime} \mathrm{N}, 22^{\circ} 22^{\prime} \mathrm{W}\right), 25$ Jul 1987, E. S. Hansen 87851 (C). Fligely $\left(74^{\circ} 49^{\prime} \mathrm{N}\right.$, $\left.20^{\circ} 45^{\prime} \mathrm{W}\right), 31$ Jul 1988, E. S. Hansen (C).

\section{Melanelia stygia (L.) Essl. (Fig. 6, Fig. 7)}

Thallus foliose, appressed to rather strongly pulvinate or rarely ascendant, tightly to moderately or even loosely adnate, up to $11(-15) \mathrm{cm}$ in diameter. Lobes $0.5-2 \mathrm{~mm}$ broad, occasionally weakly and irregularly concave but more often flat to rather moderately convex, rarely almost terete (the ascendant lobes), usually elongate or linear-elongate, contiguous to imbricate (or entangled in the ascendant form). Upper surface dark olive-brown to dark brown or blackbrown, smooth on the lobe ends, inward smooth to often plicate or rugose, dull throughout or more often shiny, especially at the periphery; without soredia or typical isidia, but occasion- 

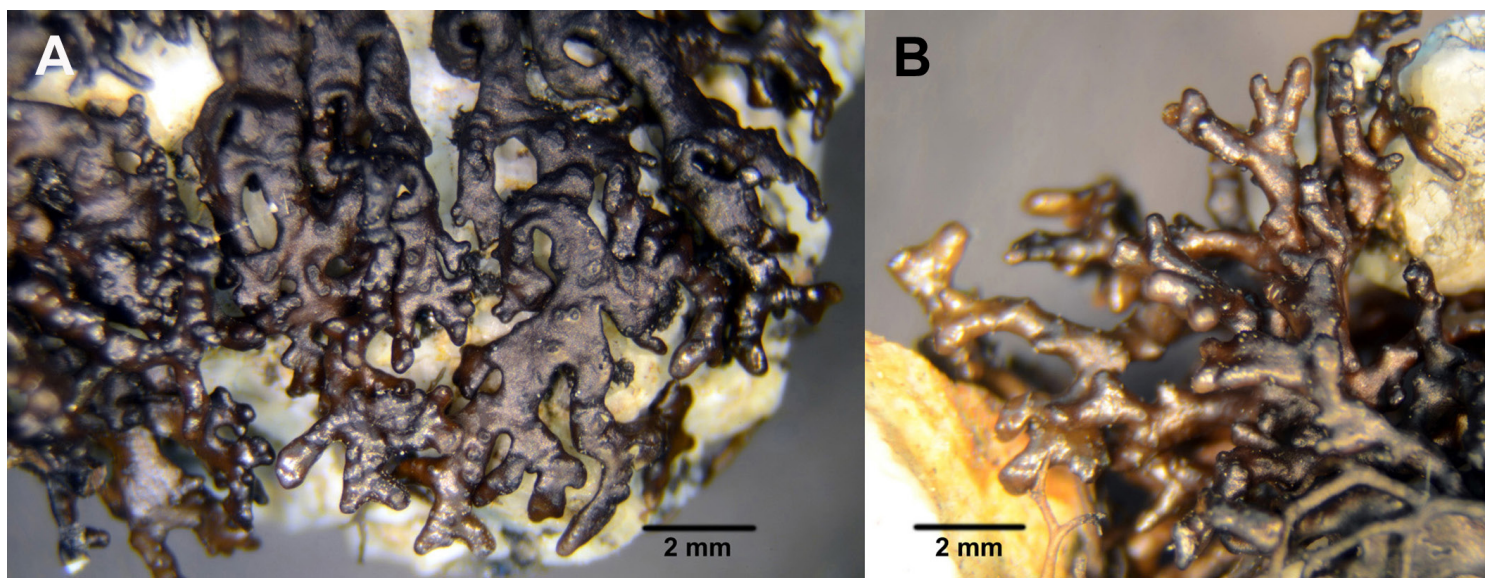

Fig. 6. Melanelia stygia [Alstrup 7431 (C)]. A - Prostrate portion of thallus with flat lobes. B - Upright portion of the same thallus, with more terete lobes.

ally with spherical to clavate isidioid papillae which sometimes elongate to form dorsiventral lobules or terete, branched, upright lobes; usually with numerous and conspicuous, laminal pseudocyphellae, these whitish to darkening. Lower surface black, sometimes paler on the lobe ends, mostly smooth to weakly rugose or foveolate, moderately to sparsely rhizinate, the rhizines laminal and/or marginal, simple or sparsely furcate, black, to $1(-1.5) \mathrm{mm}$ long. Apothecia common, laminal, sessile to very short stipitate, concave to flat, up to $5(-8) \mathrm{mm}$ in diameter, the margin crenate and or warted, pseudocyphellate; ascospores 8 , ellipsoid to subglobose, 7-10.5×4.5-6 $\mu \mathrm{m}$. Pycnidia common, usually immersed but rarely very slightly emergent; conidia 3.5-5.5×1 $\mu \mathrm{m}$, bifusiform.

Thallus spot tests: cortex K-; medulla PD+ redorange and $\mathrm{K}$ dingy to $\mathrm{K}+$ dingy orange, or $\mathrm{PD}-$ and $\mathrm{K}-$, always $\mathrm{C}-$. Lichen substances: at least six different chemical races are known in this species (Esslinger, 1977) but so far only "race \# 1" [fumarprotocetetraric acid $(+++)$, protocetraric acid (+ to -) and race "\# 6" [no detectable substances] are known to occur in Greenland.

Substrate and ecology: grows on siliceous and, more rarely, basaltic rocks; like $M$. agnata, $M$. stygia is particularly common on different rocks belonging to the Ilimaussaq intrusion in the Julianehåb district and probably is suitable as indicator of rocks rich in rare minerals and metals (Ferguson, 1964).

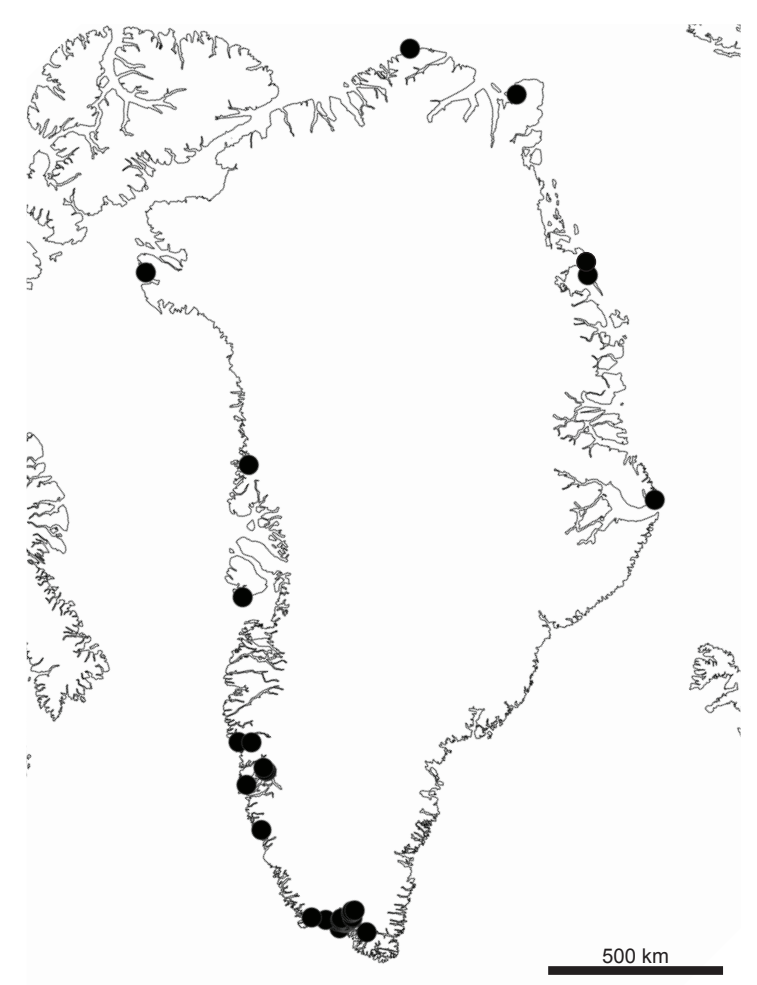

Fig. 7. Distribution of Melanelia stygia in Greenland. 
Distribution: widely distributed in West Greenland (Dahl, 1950; Alstrup, 1979; Hansen, 2009, 2012) and occuring scattered in Central East Greenland from Ittoqqortoormiit to Station Nord (Hansen, 1995b) . It has so far not been found in South East Greenland.

Discussion: Especially when considering the world distribution, this species is certainly one of the most variable species among the brown parmelioid lichens. The important diagnostic characters for the species are the black lower surface, usually occurring with more or less sparse laminal rhizines, and the upper surface with usually conspicuous laminal pseudocyphellae. Specimens containing fumarprotocetraric acid are relatively easy to distinguish because of the strong $\mathrm{PD}+$ orange-red reaction (although one must carefully discern this from the often PD+ pale to golden-yellow reaction of $M$. hepatizon due to stictic $\&$ norstictic acid). Specimens with some upright, more or less terete lobes (Fig. 6B) are common in Greenland, and many of them show a nice transition from the more typical prostrate form in the same collection.

In Greenland, and other areas of the far north, specimens of Montanelia disjuncta sometimes lack soralia (especially if small or poorly developed, but sometimes in even well-developed thalli), and are sometimes misidentified as a PDform of $M$. stygia. Pseudocyphellae of $M$. stygia are usually clearly laminal, while those of $M$. disjuncta are submarginal and more obscure. One quick easy way to tell the two apart is the very soft, easily shattered cortex of $M$. disjuncta and the thicker, and much firmer, cartilaginous cortex of M. stygia. Of course, the chemistry of the two is very different.

Because of its dark color and black lower surface, unrelated Allantoparmelia alpicola (Th. Fr.) Essl. is sometimes misidentified as $M$. stygia, but they should not be easily confusable, since A. alpicola lacks pseudocyphellae and rhizines, and has very different spot test reactions (medulla $\mathrm{PD}+$ strong yellow, $\mathrm{C}-$ to $\mathrm{C}+$ rose, and $\mathrm{KC}+$ rose-red).

Selected specimens examined (from a total of 73): Kvanefjeld $\left(60^{\circ} 59^{\prime} \mathrm{N}, 45^{\circ} 59^{\prime} \mathrm{W}\right)$, alt. $545 \mathrm{~m}, 24 \mathrm{Jul}$ 1978, V. Alstrup 243933 (C). Godthåbsfjord, Ilualik, Igdlorssuit $\left(64^{\circ} 48^{\prime} \mathrm{N}, 50^{\circ} 42^{\prime} \mathrm{W}\right), 31$ Jul $1976, E$. S. Hansen 76569 (C). Blæsedalen $\left(69^{\circ} 16^{\prime} \mathrm{N}, 53^{\circ} 30^{\prime} \mathrm{W}\right)$, alt. 25 m, 2 Aug 1958, K. Hansen 925 (C). Itoqqortoormiit $\left(70^{\circ} 29^{\prime} \mathrm{N}, 21^{\circ} 58^{\prime} \mathrm{W}\right), 22$ Jul 1987, E. S. Hansen 87691
(C). Station Nord, Knuth Fjeld $\left(81^{\circ} 34^{\prime} \mathrm{N}, 16^{\circ} 24^{\prime} \mathrm{W}\right), 24$ Aug 1995, E. S. Hansen 95919 (C)

Melanelixia Glabratula (Lamy) Sandler \& Arup Thallus foliose, appressed throughout or somewhat reflexed at the periphery, loosely to moderately adnate, up to $7(-10) \mathrm{cm}$ in diameter. Lobes 1-3(-5) mm broad, more or less flat, short and rounded to somewhat elongate, contiguous to imbricate. Upper surface pale olive-green to olive-brown or reddish-brown, smooth to weakly and irregularly pitted and/or wrinkled, rarely becoming lobulate in the center; dull to more often strongly shiny, especially near the periphery; without pseudocyphellae; isidiate, the isidia sparse to dense, more or less cylindrical, often branched, attenuate or distinctly knobbed at the end, up to $1(-1.5) \mathrm{mm}$ long and 0.05-0.1(-0.5) $\mathrm{mm}$ in diameter, easily and frequently broken off near the base and leaving conspicuous white spots. Lower surface dark brown to black, somewhat paler near the periphery; occasionally almost smooth but more often rather evenly rugulose, usually distinctly shiny, occasionally dull; moderately rhizinate, the rhizines more or less concolorous with the lower surface. Apothecia occasional, laminal, sessile, concave to flattening or somewhat irregular, up to $6 \mathrm{~mm}$ in diameter, the margin entire when small, soon papillate and/or isidiate, easily and commonly eroded; ascospores 8 , ellipsoid to rarely almost subglobose, 10-14×5.5-9.5 $\mu \mathrm{m}$. Pycnidia rare, laminal, immersed; conidia $6-7.5 \times 1 \mu \mathrm{m}$, weakly bifusiform.

Thallus spot tests: cortex $\mathrm{K}-$, medulla PD-, K(or $\mathrm{K}+$ violet in pigmented parts), $\mathrm{C}+$ red. Lichen substances: lecanoric acid (+++), with smaller amounts of 5-methoxylecanoric acid (+ to trace), and sometimes skyrin (as scattered pigment patches in the lower part of the medulla).

Substrate \& ecology: on bark or wood.

Distribution: known from only the single locality cited below, collected on bark of Picea; apparently introduced (Alstrup, 1977).

Discussion: This species is known in Greenland from only a single, somewhat fragmentary but typical, specimen. Because of the rarity and small size, this specimen was not sampled for TLC, but it is chemically typical, including even 
skyrin pigmentation scattered on exposed medullary tissues of some lower surface regions.

The only similar species in Greenland is the equally rare $M$. subaurifera (also a single specimen), which is also isidiate and $\mathrm{C}+\mathrm{red}$ in the medulla. That species has much finer, usually unbranched isidia which are accompanied by soredia, and it usually has a much less shiny cortex. It contains lecanoric acid but lacks both the 5-methoxylecanoric acid and the skyrin produced by $M$. glabratula.

Specimen examined (1): Godthåbsfjord, Qornoq

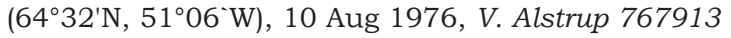
(C).

Melanelixia subaurifera (Nyl.) O. Blanco, A. Crespo, Divakar, Essl., D. Hawksw. \& Lumbsch

Thallus foliose, appressed throughout or occasionally slightly reflexed at the periphery, loosely to moderately adnate, up to $8(-10) \mathrm{cm}$ in diameter. Lobes 1-4(-6) $\mathrm{mm}$ broad, more or less flat, short and rounded to somewhat elongate, discrete to more often contiguous or subimbricate. Upper surface olive-green or olive-brown to rather dark reddish-brown, smooth to weakly foveolate or rugulose near the periphery, inward usually somewhat more strongly rugose, dull throughout or occasionally shiny, especially near the periphery; sometimes with small and very obscure, concolorous pseudocyphellae on the lobes; sorediate or isidiate or (usually) both, soralia laminal, often arising from the obscure pseudocyphellae, punctiform and discrete or becoming more or less confluent in central parts, soredia granular, frequently becoming brownish and isidioid or isidiate; isidia arising within but also between the soralia, cylindrical, not or infrequently branched, up to $0.2(-0.4) \mathrm{mm}$ long and $0.02-0.06 \mathrm{~mm}$ in diameter. Lower surface pale brown to dark brown or black, often paler at the periphery; more or less smooth to rugose, dull to rather shiny; moderately rhizinate, the rhizines concolorous with the lower surface. Apothecia rare, laminal, sessile, more or less flat, up to $2.5 \mathrm{~mm}$ in diameter, the margin entire when young, soon sorediate and isidiate; ascospores 8 , ellipsoid $10-13 \times 5.5-7 \mu \mathrm{m}$. Pycnidia rare, laminal, immersed; conidia $5.5-7 \times 1 \mu \mathrm{m}$, weakly fusiform to weakly bifusiform.

Spot test reactions: cortex K-; medulla $\mathrm{P}-$, K-, $\mathrm{C}+$ rose-red or red. Lichen substance: lecanoric acid.
Substrate \& ecology: normally corticolous, here known only from a rocky cave.

Distribution: found growing in a rocky cave influenced by nutritient dust at Engelskmandens Havn on Disko (Gelting, 1956); the specimens are apparently misplaced.

Discussion: Very rare and probably introduced, only one locality for this species is known in Greenland. This species can be distinguished from the similar isidiate species M. glabratula by the presence of soredia in addition to isidia on the lamina. The isidia of $M$. subaurifera are also much finer and develop both within and between the soralia. Both species produce lecanoric acid, but $M$. subaurifera lacks the 5-methoxylecanoric acid and scattered skyrin found in M. glabratula.

Specimen examined (1): Disko, Engelskmandens Havn $\left(69^{\circ} 15^{\prime} \mathrm{N}, 53^{\circ} 35^{`} \mathrm{~W}\right), 1950$, P. Gelting 12709 (C).

Melanohalea elegantula (Zahlbr.) O. Blanco, A. Crespo, Divakar, Essl., D. Hawksw. \& Lumbsch (Fig. 8, Fig. 9)

Thallus foliose, more or less appressed throughout or somewhat raised near periphery, moderately to loosely adnate, up to $6(-10) \mathrm{cm}$ in diameter. Lobes $1-4(-7) \mathrm{mm}$ broad, more or less flat, short and rounded to slightly elongate, more or less contiguous to imbricate. Upper surface pale olive-green to dark olive-brown, red-brown or darkening, more or less smooth to irregularly and slightly pitted or wrinkled; usually dull, occasionally weakly shiny, especially near the lobe-ends, frequently with a scattered to more continuous pruina (esp. saxicolous specimens); isidiate, the isidia arising near the lobe-ends as small rather evenly scattered, conical to hemispherical papillae (not constricted at the base) with obscure to distinct pseudocyphellae at the tips, growing into usually more or less cylindric isidia up to 1 or occasionally $1.5 \mathrm{~mm}$ long and (0.03-)0.05-0.2(-0.4) $\mathrm{mm}$ in diameter, often developing unequal branches. Lower surface pale tan to dark brown or blackening, generally paler near the periphery, or often mottled pale and dark throughout; smooth to irregularly wrinkled or even trabeculate in spots, dull to slightly shiny, moderately to somewhat sparsely rhizinate, the rhizines scattered, mostly concolorous with the lower surface. Apothecia infrequent (not seen in Greenland), laminal, sessile or very short stipitate, concave or flattening, 


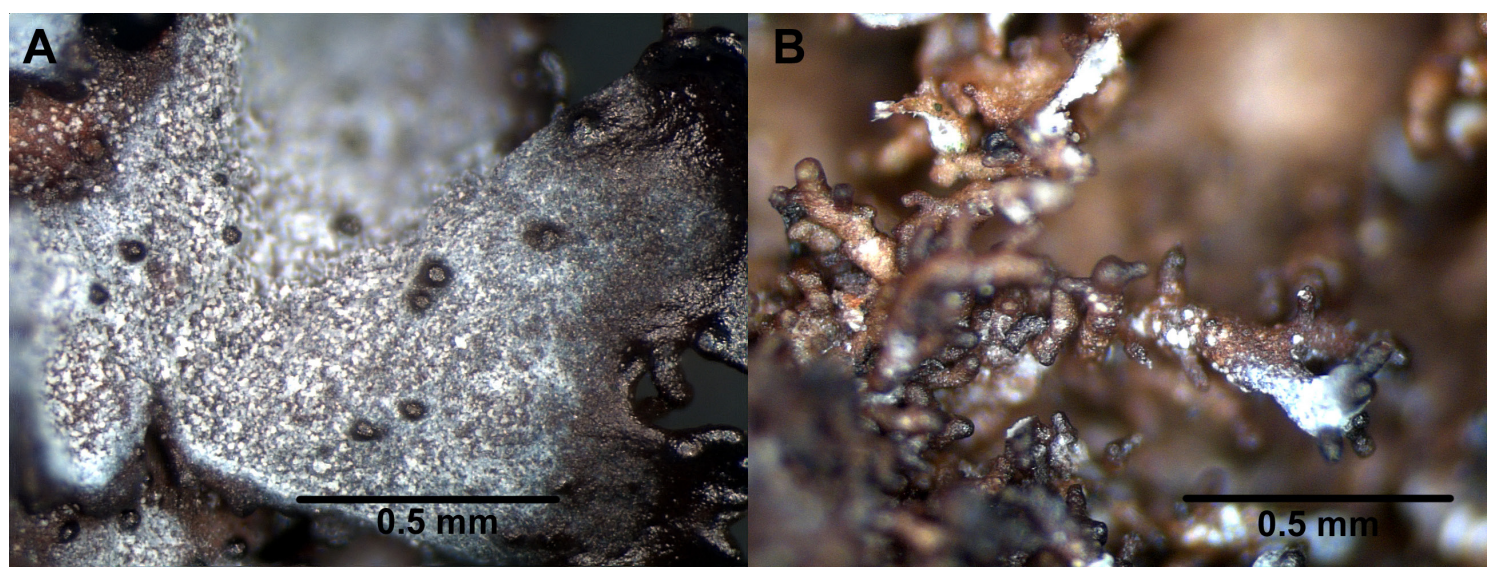

Fig. 8. Dark, saxicolous ecotype of Melanohalea elegantula [Hansen 09B.278 (C)]. A - Peripheral lobe bearing scattered, pseudocyphellate papillae which grow into isidia. B - Isidia from more mature region of thallus, showing irregular branching with small, often darkened side branches.

up to $3.5 \mathrm{~mm}$ in diameter, the margin entire to crenulate at first, becoming papillate to strongly isidiate; ascospores 8 , ellipsoid to broadly ovoid or occasionally almost subglobose, 8-11.5×4.5-7 $\mu \mathrm{m}$. Pycnidia rare, laminal, immersed; conidia ca. $7 \times 1 \mu \mathrm{m}$, acicular to fusiform.

Thallus spot tests: cortex $\mathrm{K}-$, medulla PD-, K-, $\mathrm{C}-$, KC-. Lichen substances: none.

Substrate \& ecology: saxicolous, growing on siliceous and basaltic rocks influenced by guano, and it has a distinct preference for top faces of such rocks; occasional on gravel and soil below bird rocks (although commonly also corticolous / lignicolous in most of its range in North America and Eurasia, not yet seen on these substrates in Greenland).

Distribution: widely distributed in Greenland; occurs scattered in the southernmost part of South West and South East Greenland (Dahl et al., 1937; Dahl, 1950; Hansen, 1971; Hansen, 1978 a \& b) and fairly common in Central West, North West and North East Greenland, and even at the north coast of Greenland (Alstrup et al., 2000; Hansen, 2001, 2002).

Discussion: Using the classical European concept of $M$. elegantula as a strictly corticolous or lignicolous species, with all similar isidiate material from rock being assigned to $M$. infumata, only about two Greenland specimens would be determined as $M$. elegantula. It was long ago pointed out (Esslinger, 1977), however, that while $M$. infumata is indeed an obligately saxicolous species, M. elegantula occurs commonly on both bark and rock. A lengthy discussion of the intricacies of delimiting these two taxa was provided in that paper, although it seems to have been largely ignored or misunderstood, resulting for instance in the most recent treatment of European Parmeliaceae (Thell \& Moberg, 2011) still referring to $M$. elegantula as a strictly corticolous species with (in Nordic countries) a southern distribution, and commenting only that "further studies are required."

Since the time of that original publication (Esslinger, 1977), the first author has studied hundreds more specimens of purported $M$. elegantula and $M$. infumata, including much material from central and northern Europe, all of which has served only to reinforce the taxonomic and biogeographic views expressed at that time. Study of a large series of specimens housed at GZU confirmed that $M$. infumata appears to be absent from central Europe (France, Austria, Switzerland) and points south. Delimitation of these two taxa should be based primarily on the form and development of the isidia ( $\&$ not substrate) and this fact has now also been confirmed by genetic studies (Leavitt et al., 2013, 2014), which show not only that M. elegantula is commonly saxicolous as well as corticolous, but also show that it is not even particularly closely related to $M$. infumata. 


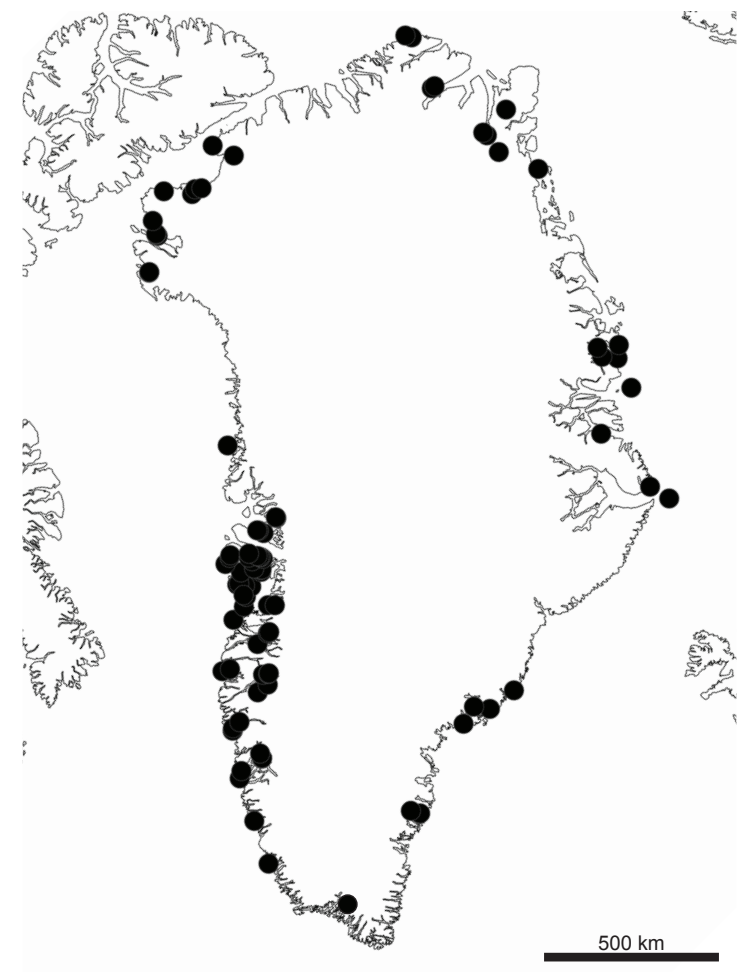

Fig. 9. Distribution of Melanohalea elegantula in Greenland.

The isidia of $M$. elegantula develop from small cone shaped papillae which bear distinct to very obscure pseudocyphellae at their tip (Fig. 8A). These papillae are typically forming fairly close to the lobe ends and grow into isidia in a centripetal fashion with the most mature isidia generally clustering in the older parts of the thallus. Although the main body of the isidium sometimes branches, more often there are one to four side branches, which are much smaller in diameter than the isidium on which they are borne. By contrast, the isidia of $M$. infumata develop from more or less spherical papillae (Fig. 11A) which do not bear pseudocyphellae and are not necessarily restricted to the thallus periphery, sometimes therefore occurring also intermixed among mature isidia. They grow into isidia that are branched or unbranched. When branches occur, they are typically similar in diameter to the main part of the isidium although not necessarily of the same length. See Esslinger (1977, fig. 70 \& 71) for more discussion and an illustration of isidial variation in these two taxa.
Well developed and typical specimens of $M$. elegantula and $M$. infumata are quite distinctive and easily distinguished from one another. However, with poorly developed and atypical specimens, which are especially frequent in harsh environments like that of Greenland or other far northern regions, the two taxa can sometimes look remarkably alike and be difficult to determine. If one examines every specimen expecting to see each and every one of the distinguishing characters described here, failure is likely. It's not always possible to see all the character differences in such poor or mediocre specimens. For recognition of $M$. elegantula, for instance, it is usually enough to see either the faintly pseudocyphellate papillae or a few of the characteristic isidia with smaller side branches, although careful examination will usually reveal both.

Selected specimens examined (from a total of 186): Kangerlussuaq, Mt. Hassel $\left(67^{\circ} 02^{\prime} \mathrm{N}, 50^{\circ} 40^{\prime} \mathrm{W}\right)$, alt. 250 m, 2 Aug 1946, M. Skytte Christiansen 5459 (C). Qaarsut $\left(70^{\circ} 44^{\prime} \mathrm{N}, 52^{\circ} 32 ' \mathrm{~W}\right), 26$ Jul 2003, E. S. Hansen

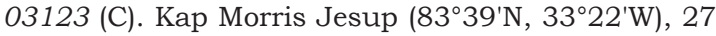
Jul 2007, E. S. Hansen 07080 (C). Isertoq $\left(65^{\circ} 39^{\prime} \mathrm{N}\right.$, 38 24'W), 23 Aug 1971, E. S. Hansen 711230 (C). Clavering $\varnothing$, Theodoltplateauet $\left(74^{\circ} 22 ' \mathrm{~N}, 21^{\circ} 23^{\prime} \mathrm{W}\right)$, 29 Jul 1994, E. S. Hansen 94295 (C).

Melanohalea exasperata (De Not.) O. Blanco, A. Crespo, Divakar, Essl., D. Hawksw. \& Lumbsch Thallus foliose, more or less appressed throughout, moderately adnate, up to $7(-10) \mathrm{cm}$ in diameter. Lobes $1-4(-6) \mathrm{mm}$ broad, flat to weakly convex, short and rounded to slightly elongate, discrete to more often contiguous or somewhat imbricate. Upper surface olive-brown to darkbrown, often somewhat paler at the periphery, smooth throughout or becoming irregularly rugose in the central parts, dull or occasionally rather shiny, especially near the periphery, commonly pruinose in part or in whole; without soredia or isidia; but with numerous, more or less evenly scattered, conical to shortcylindric papillae, $0.05-0.15(-0.25) \mathrm{mm}$ long and $0.05-0.1(-0.12) \mathrm{mm}$ in diameter, each bearing a conspicuous pseudocyphella at the tip. Lower surface dark brown to black centrally, often much paler at the periphery, more or less flat and smooth to irregularly wrinkled, dull to slightly shiny, moderately rhizinate, the rhizines scattered, more or less concolorous with the lower surface, the marginal ones often project- 
ing laterally and visible from above. Apothecia common and often numerous, laminal, sessile to very short stipitate, somewhat concave or flattening, up to $6(-8) \mathrm{mm}$ in diameter, the margin very soon developing pseudocyphellate papillae like those on the thallus; ascospores 8, ellipsoid to somewhat ovoid, $8.5-12 \times 5-7 \mu \mathrm{m}$. Pycnidia common, laminal and immersed; conidia 7-8 $\times$ ca. $1 \mu \mathrm{m}$, acicular to weakly fusiform.

Thallus spot tests: cortex $\mathrm{K}-$; medulla PD-, K-, $\mathrm{CK}-, \mathrm{KC}-$. Lichen substances: none.

Substrate \& ecology: on bark or wood.

Distribution: known from only the single locality cited below, growing on wood of Pinus; apparently introduced (Alstrup, 1977).

Discussion: This is one of the more easily identified species of Melanohalea, readily distinguished by the prominent, rather evenly scattered papillae on the upper surface, each with a pseudocyphella at the top. The single Greenland specimen is small and fragmentary but very typical.

Specimen examined (1): Nordlandet, Sardloq, alt. $10 \mathrm{~m},\left(64^{\circ} 23^{\prime} \mathrm{N}, 51^{\circ} 42^{\prime} \mathrm{W}\right), 14$ Aug 1976, V. Alstrup $76882(\mathrm{C})$.

Melanohalea exasperatula (Nyl.) O. Blanco, A. Crespo, Divakar, Essl., D. Hawksw. \& Lumbsch (Fig. 10)

Thallus foliose, appressed throughout or more often somewhat raised at the periphery, loosely to moderately adnate, up to $5 \mathrm{~cm}$ in diameter. Lobes (1-)2-5 mm broad, flat but often with reflexed margins, broadly rounded, contiguous to more or less imbricate. Upper surface pale olive-green to dark olive-brown or red-brown, smooth to slightly and irregularly wrinkled or occasionally more or less shallowly and reticulately pitted, often very shiny, especially near the periphery, occasionally with a scattered, light pruina; usually without pseudocyphellae, though rarely with tiny fleck-like rough spots on lobes. Isidiate, the isidia arising as small hemispherical to spherical papillae which enlarge to form inflated, spherical or more often clavate to spatulate isidia, $0.3-1(-2) \mathrm{mm}$ long, unbranched but sometimes becoming knotched or bifurcate at the tip, rarely developing a few tiny, rhizine-like papillae on one surface. Lower surface pale tan to dark brown or rarely blackening, uniform or mottled, more or less flat and smooth to irregularly or reticulately wrinkled, more or less shiny or becoming dull, especially inward, moderately rhizinate, the rhizines more or less concolorous with the lower surface or paler. Apothecia uncommon, laminal, more or less sessile, weakly concave or flattening, up to $3 \mathrm{~mm}$ in diameter, the margin at first entire, becoming crenate or crenate-papillate; ascospores 8 , broadly ellipsoid to almost subglobose, 8-10.5×5.5-8 $\mu \mathrm{m}$. Pycnidia not seen.

Thallus spot tests: cortex $\mathrm{K}-$, medulla PD -, K -, $\mathrm{C}-, \mathrm{KC}-$. Lichen substances: none.

Substrate \& ecology: bark or wood, occasional on rock; in Greenland, occurring on bark of dwarf shrubs, Picea wood, and on siliceous and basaltic rocks, preferably in somewhat enriched sites.

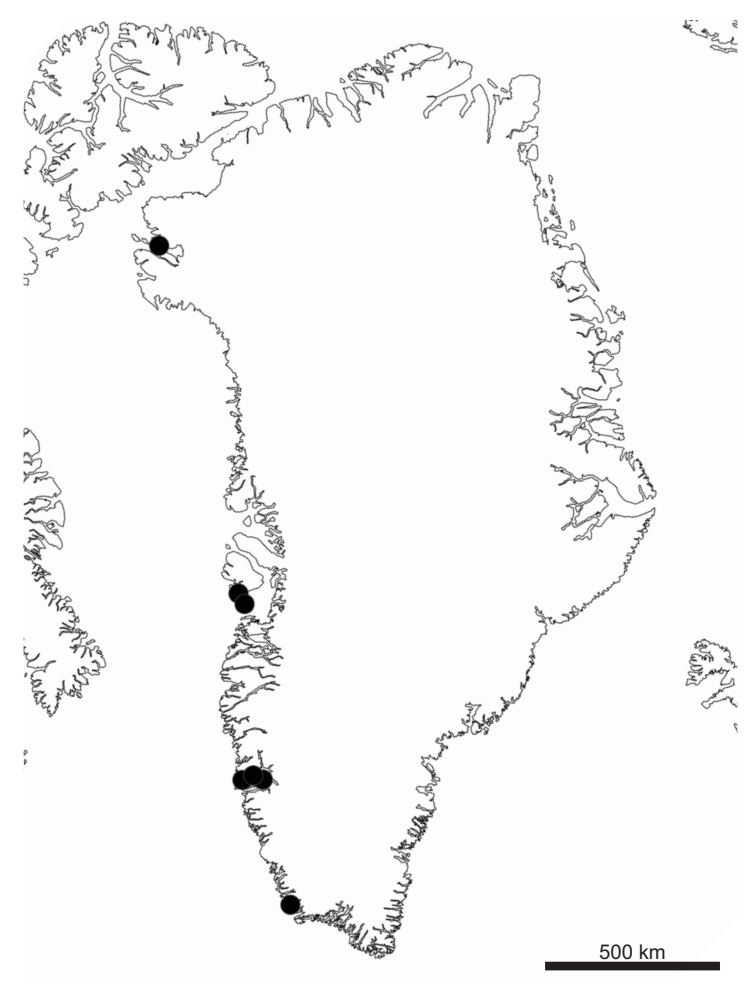

Fig. 10. Distribution of Melanohalea exasperatula in Greenland. 
Distribution: known from a few localities in South West, Central West and North West Greenland; not known so far from East or North Greenland; first reported as possibly introduced (Alstrup, 1977), but that was later corrected (Alstrup, 1982).

Discussion: This usually corticolous species is rare in Greenland, where it occurs on rock as frequently as on bark or wood. The inflated, often clavate isidia distinguish it readily from the other isidiate species of Melanohalea, although the saxicolous specimens have been at times misidentified as $M$. infumata, perhaps largely because of their somewhat unexpected substrate.

Specimens examined (7): N. Sermilik, Tasiussaq (6109' N, 4540'W), 29 Jul 1937, E. Dahl (C). Arsuk (6111'N, 4828'W), 10 Jul 1993, E. S. Hansen 93502 (C). Tavtait $\left(64^{\circ} 27^{\prime} \mathrm{N}, 50^{\circ} 31^{\prime} \mathrm{W}\right), 26$ Jul 1979, V. Alstrup 69121 (C). Godthåbsfjord, Qornoq $\left(64^{\circ} 32^{\prime} \mathrm{N}\right.$, 51ํㅡ'W), 10 Aug 1976, V. Alstrup 767915 (C). Disko, Qeqertarsuaq $\left(69^{\circ} 15^{\prime} \mathrm{N}, 53^{\circ} 15^{\prime} \mathrm{W}\right), 31 \mathrm{Jul} 1982$, J. Poelt $\&$ H. Ullich $(\mathrm{C})$. Qeqertarsuaq, Elvestubben $\left(69^{\circ} 15^{\prime} \mathrm{N}\right.$, $\left.53^{\circ} 15^{\prime} \mathrm{W}\right)$, alt. $30 \mathrm{~m}, 8$ Aug 1950, P. Gelting (C). Qaanaaq $\left(77^{\circ} 28^{\prime} \mathrm{N}, 69^{\circ} 06^{\prime} \mathrm{W}\right)$, alt. $15 \mathrm{~m}, 18 \mathrm{Jul} 1992, V$. Alstrup 92027 (C).

Melanohalea infumata (Nyl.) O. Blanco, A. Crespo, Divakar, Essl., D. Hawksw. \& Lumbsch (Fig. 11, Fig. 12)

Thallus foliose, more or less appressed throughout, moderately to loosely adnate, $2-7(-10) \mathrm{cm}$ in diameter. Lobes $1-4(-6) \mathrm{mm}$ broad, more or less flat to slightly convex, short and rounded or frequently rather elongate and slightly sinuous, discrete to contiguous or subimbricate. Upper surface pale olive-green to more often dark redbrown, occasionally somewhat blackish-brown; smooth and flat to shallowly and irregularly pitted, usually rather dull throughout but occasionally shiny on the lobe-ends, frequently pruinose although this is usually light and commonly restricted toward the lobe-ends; without soredia or pseudocyphellae; sparsely to somewhat densely isidiate, the isidia arising as small hemispherical to spherical papillae, these enlarging and elongating to form cylindrical (but often somewhat irregular or sinuous), simple or branched isidia, $0.2-1(-2) \mathrm{mm}$ long and $0.07-0.12 \mathrm{~mm}$ in diameter, sometimes rather distinctly hollow. Lower surface often dark brown to black, generally paler near the lobe-ends and sometimes mottled dark and light throughout, smooth or irregularly wrinkled or weakly trabeculate, sometimes appearing slightly convex or channelled (due to turned down lobe margins), dull to slightly shiny in part; moderately to sparsely rhizinate, the rhizines concolorous with the lower surface or pale, occasionally with a weak marginal tendency. Apothecia and pycnidia unknown.

Thallus spot tests: cortex $\mathrm{K}-$; medulla $\mathrm{PD}-, \mathrm{K}-$, $\mathrm{C}-, \mathrm{CK}-, \mathrm{KC}-$. Lichen substances: none.

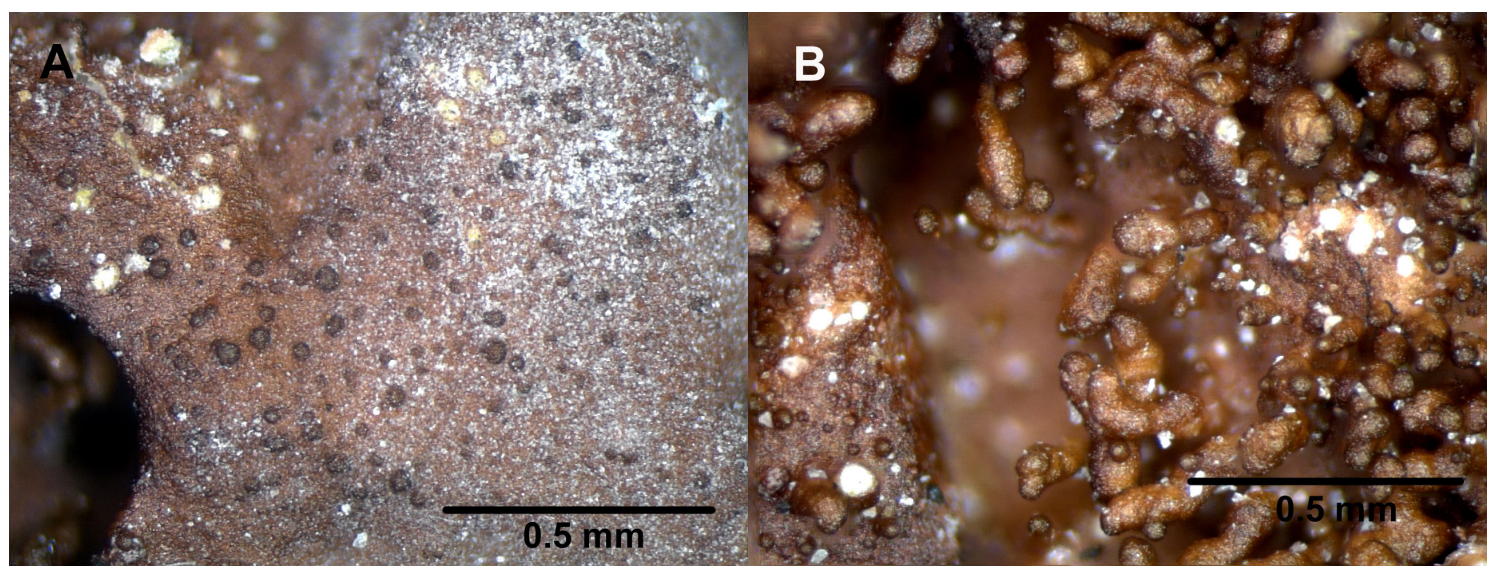

Fig. 11. Melanohalea infumata [Hansen 08.265 (C)]. A - Peripheral lobe, bearing scattered, hemispherical (\& non-pseudocyphellate) papillae which grow into isidia. B - Isidia from more mature region of thallus, showing irregular branching (note almost inflated appearance of some isidia, and presence of small papillae still in this portion of the thallus). 
Substrate \& ecology: on rock; in Greenland it occurs on siliceous and basaltic rocks, often with visible influence of guano, and sometimes also over mosses on such rocks.

Distribution: known from many localities in the southernmost part of South West Greenland (Dahl, 1950; Hansen, 1978a), and from two localities in Central West Greenland.

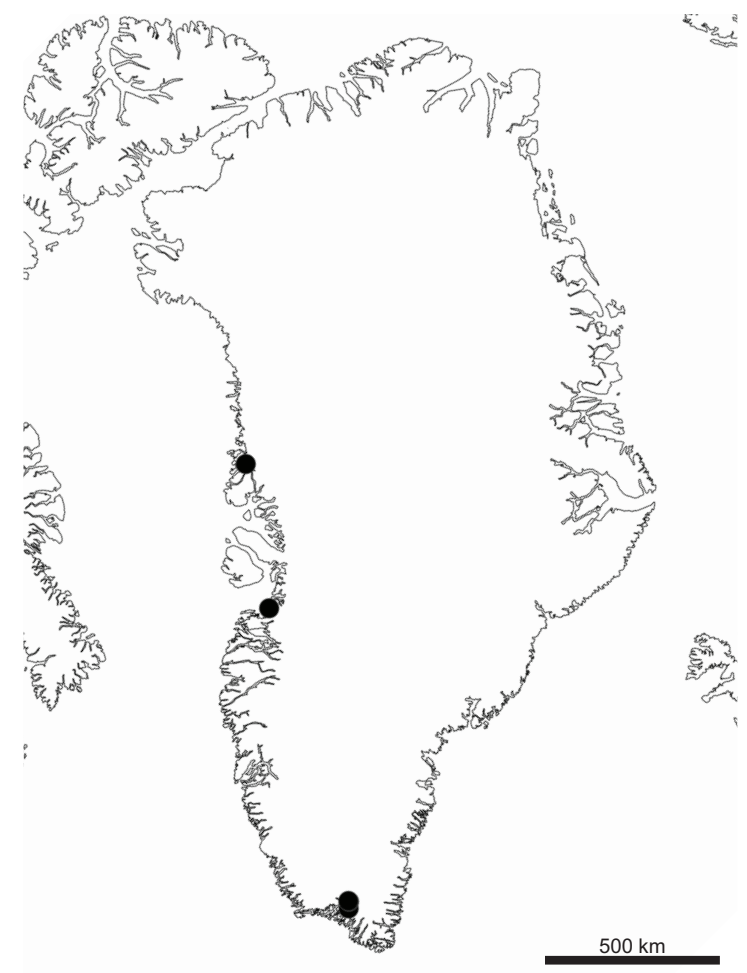

Fig. 12. Distribution of Melanohalea infumata in Greenland.

Discussion: Melanohalea infumata, which is restricted almost totally to rock substrates, has long and frequently been confused with the much more common and widespread isidiate species M. elegantula, which occurs commonly on rock as well as on bark or wood substrates. Although the two can appear very similar, the genetic evidence shows that they are not particularly closely related to one another (Leavitt et al., 2014) and that the morphological distinctions presented by Esslinger (1977), based largely on isidia form and development, are accurate and instructive. These distinctions are summarized in the discussion above under M. elegantula; also see Esslinger (1977) for an even more detailed discussion and illustrations.

Selected specimens examined (from a total of 12): Qagdlumiut (6043'N, 4518'W), 22 Aug. 1937, E. Dahl (C). Narssarsuaq $\left(61^{\circ} 10^{\prime} \mathrm{N}, 4^{\circ} 25^{\prime} \mathrm{W}\right), 22 \mathrm{Jul} 2008, E$. S. Hansen 08265 (C). Iterdlak $\left(61^{\circ} 11^{\prime} \mathrm{N}, 45^{\circ} 27^{\prime} \mathrm{W}\right), 16$ Jul 1969, E. S. Hansen 69332 (C). Igdluko $\left(68^{\circ} 49^{\prime} \mathrm{N}\right.$, $\left.51^{\circ} 11^{\prime} \mathrm{W}\right), 15$ Sep 1952, P. Gelting 19091 (C). Laksefjord, Eqaluarssuit $\left(72^{\circ} 29^{\prime} \mathrm{N}, 5^{\circ} 28^{\prime} \mathrm{W}\right), 20$ Aug 1951, P. Gelting 14631 (C).

Melanohalea olivacea (L.) O. Blanco, A. Crespo, Divakar, Essl., D. Hawksw. \& Lumbsch (Fig. 13)

Thallus foliose, appressed throughout or somewhat raised at the periphery, moderately to rather loosely adnate, $2-9(-14) \mathrm{cm}$ in diameter. Lobes (1-)2-6(-8) mm broad, more or less flat, short and rounded to rather elongate, discrete to rather strongly imbricate. Upper surface olivebrown to rather dark-brown, often somewhat paler at the periphery, smooth to rather strongly rugose and pitted near the periphery; inward usually more strongly rugose and sometimes tuberculate, dull throughout or rather strongly shiny, especially near the periphery, sometimes lightly to rather heavily pruinose in part; without soredia or isidia; pseudocyphellae usually rather numerous, laminal, sometimes occurring primarily on small, very weakly conical papillae. Lower surface dark brown to black, paler at the periphery, smooth to rugose; dull to somewhat shiny in part, moderately to somewhat more densely rhizinate, the rhizines more or less concolorous with the lower surface. Apothecia common, laminal, mostly central, sessile to short stipitate, more or less concave, to $9 \mathrm{~mm}$ in diameter, the margin usually becoming distinctly crenate or tuberculate, with numerous pseudocyphellae, the amphithecium surface becoming strongly rugose-foveolate in mature apothecia; subhymenial tissue (subhymenium + hypothecium) 30-80 $\mu \mathrm{m}$ thick; ascospores 8 , ellipsoid to ovoid, (9.5-)11-16×(5-)6-9 $\mu \mathrm{m}$. Pycnidia common, laminal, immersed; conidia $5.5-7(-8) \times$ ca. $1 \mu \mathrm{m}$, acicular to distinctly bifusiform.

Thallus spot tests: cortex $\mathrm{K}-$, medulla $\mathrm{PD}+$ yellow-orange to red-orange or rarely $\mathrm{PD}-, \mathrm{K}-$ to slightly yellow or (rarely) $\mathrm{K}+$ dingy yellow-orange, $\mathrm{C}-, \mathrm{KC}-$. Lichen substances: fumarprotocetraric acid (+++) and protocetraric acid (++ to -); rarely no substances present. 
Substrate \& ecology: on bark or wood; the Sermilik specimen on bark of dwarf shrubs, and the Qornoq specimen was growing on imported timber, and has apparently been introduced (Alstrup, 1977).

Distribution: known from only two localities in South West Greenland, Sermilik and Qornoq.

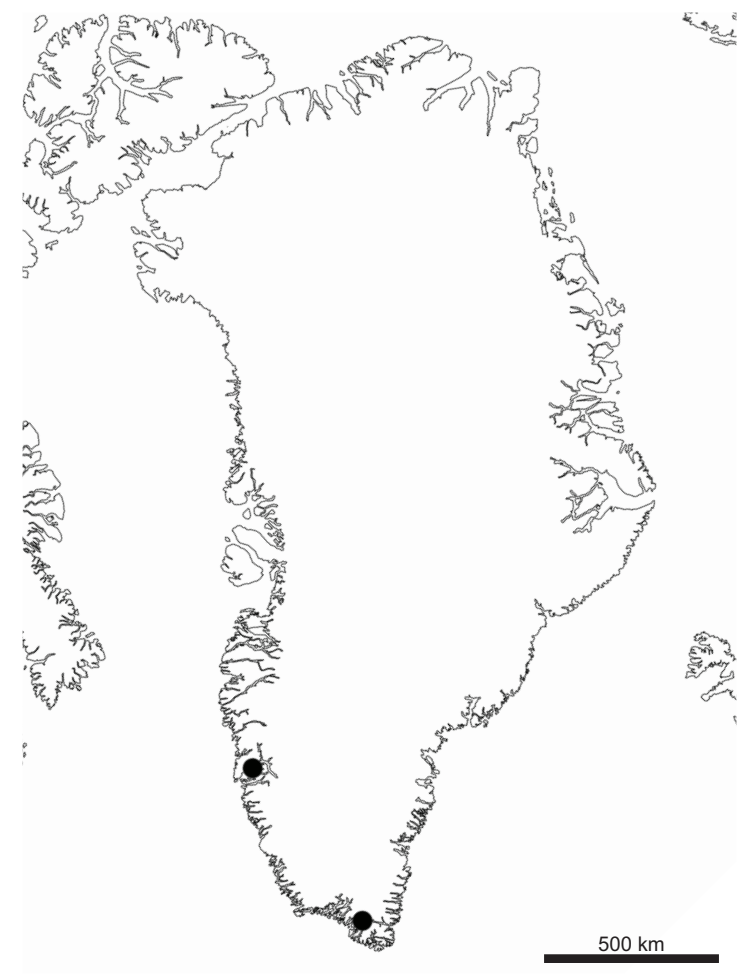

Fig. 13. Distribution of Melanohalea olivacea in Greenland.

Discussion: The only species likely to be confused with $M$. olivacea is $M$. septentrionalis, which was first recognized as a distinct taxon at the varietal level by Lynge (1912). It was first raised to the species level by Ahti (1966) and has generally been accepted at that level ever since. While discussing differences between the two taxa, most authors have pointed out the occasional difficulties of distinguishing between the two caused by the significant overlap in some of their distinguishing characters, e.g. thallus size, lobe width, apothecium size and arrangement, ascospore size, and internal apothecial dimen- sions. Recently, a detailed study by Truong et al. (2009) confirmed the difficulties of determination caused by this overlap, but was able to show statistically that the two species can and should be recognized. This conclusion was also confirmed recently using molecular techniques in studies using several dozens of specimens of both taxa (Leavitt et al., 2013, 2014).

In Greenland, Melanohalea olivacea is much less common than $M$. septentrionalis, being represented by two less than rich collections, and may represent another example of an introduced lichen species (Alstrup, 1977). Despite the attention these two species have received, poorly developed or inadequate specimens can still be difficult to identify with certainty. Regarding external morphological features, Truong et al. (2009) emphasized especially the position and shape of the pseudocyphellae (laminal and punctiform in $M$. olivacea and marginal and more elongate in $M$. septentrionalis), but even with good material these character states intergrade more than implied by those authors, and when attempting to identify less adequate material, this distinction can be impossible to make. If fully mature apothecia are present, the strongly crenulate and pseudocyphellate apothecial margins with a rugose-foveolate amphithecial surface (lower side of apothecia) clearly differ from those of $M$. septentrionalis, which are nearly entire, sparsely pseudocyphellate, and have a mostly smooth amphithecial surface. After studying hundreds of specimens of the two species, we have found the most reliable internal character to be the thickness of the subhymenial tissue in the apothecia (30-80 $\mu \mathrm{m}$ in $M$. olivacea and 8-35 $\mu \mathrm{m}$ in $M$. septentrionalis), also one of the important anatomical characters most recommended by Truong et al. (2009).

Specimens examined (2): Sermilik, alt. $50 \mathrm{~m}\left(60^{\circ} 37^{\prime} \mathrm{N}\right.$, $\left.44^{\circ} 42^{\prime} \mathrm{W}\right), 3$ Aug 1962, K. Hansen 1317 (C). Godthåbsfjord, Qornoq (64 ํㅡ' N, $51^{\circ}$ O6' W, 10 Aug 1976, V. Alstrup 767910 (C).

Melanohalea septentrionalis (Lynge) O. Blanco, A. Crespo, Divakar, Essl., D. Hawksw. \& Lumbsch (Fig. 14)

Thallus foliose, appressed, moderately to rather loosely adnate, $1-5(-7) \mathrm{cm}$ in diameter. Lobes (0.5-) 1-3(-4) mm broad, flat to slightly convex, short and rounded to slightly elongate, discrete to imbricate. Upper surface olive-brown to dark 
brown, smooth to slightly rugose or pitted near the periphery, inward usually more rugose, dull throughout or rather strongly shiny, especially near the periphery, occasionally lightly pruinose in part; without soredia or isidia; pseudocyphellae rarely numerous, laminal or at times mostly near the lobe edges. Lower surface occasionally pale brown but usually dark brown or black, smooth to rugose, dull to slightly shiny, moderately to somewhat more densely rhizinate, the rhizines concolorous with the lower surface. Apothecia common, laminal, usually extending to the periphery, more or less sessile, concave when young and occasionally remaining so but often becoming convex with age, up to $3(-5) \mathrm{cm}$ in diameter; margin entire to weakly crenulate, with few to many pseudocyphellae, the amphithecial surface usually smooth; subhymenial tissue (subhymenium + hypothecium) usually thin, 8-35(-45) $\mu \mathrm{m}$ thick; ascospores 8, ellipsoid, 9-13(-15) ×5.5-8.5 $\mu \mathrm{m}$. Pycnidia common, laminal, immersed; conidia 5-6.5×1 $\mu \mathrm{m}$, acicular to slightly bifusiform.

Thallus spot tests: cortex $\mathrm{K}-$, medulla $\mathrm{PD}+$ yellow-orange to red-orange or rarely $\mathrm{PD}-, \mathrm{K}$ - or rarely slightly yellow to yellow-orange, $\mathrm{C}-, \mathrm{KC}-$. Lichen substances: fumarprotocetraric acid $(+++)$, protocetraric acid (+ or -$)$; occasionally no substances present ( 9 of the 69 collections had at least some thalli that are PD-).

Substrate \& ecology: grows on bark of Alnus crispa, Betula nana, B. pubescens and Salix glauca; occasional on wood.

Distribution: common in South West Greenland, particularly in the extensive, south-exposed thickets; occurs more scattered in Central West Greenland as far northwards as Disko, Nuussuaq and Maarmorilik (Hansen, 1971; Alstrup, 1982; Hansen, 1978a, 1991). The species has a distinct continental distribution in Greenland.

Discussion: This species is most likely to be confused with $M$. olivacea, which is a generally larger species with larger external and internal dimensions in the apothecia. See the discussion above, under that species.

Selected specimens examined (from a total of 69): Grønnedal $\left(61^{\circ} 14^{\prime} \mathrm{N}, 48^{\circ} 05^{\prime} \mathrm{W}\right)$, alt. $25 \mathrm{~m}, 11 \mathrm{Jul}$ 1946, M. Skytte Christiansen 1211 (C). Godthåbsfjord $\left(64^{\circ} 47^{\prime} \mathrm{N}, 50^{\circ} 36^{\prime} \mathrm{W}\right)$, alt. $100 \mathrm{~m}, 20$ Aug 1976, V. Alstrup $76104(\mathrm{C})$. Arfersiorfik fjord, Iterfiluk $\left(68^{\circ} 12^{\prime} \mathrm{N}\right.$,
52³0'W), 26 Sep 1951, P. Gelting 15826 (C). Mellemfjord, Narsarssuaq $\left(69^{\circ} 44^{\prime} \mathrm{N}, 5^{\circ} 38^{\prime} \mathrm{W}\right), 25$ Sep 1953, $P$. Gelting 21459 (C). Nuussuaq peninsula, Saqqaqdalen $\left(70^{\circ} 03^{\prime} \mathrm{N}, 52^{\circ} 08^{\prime} \mathrm{W}\right), 4$ Aug $1974, N$. U. Hansen (C).

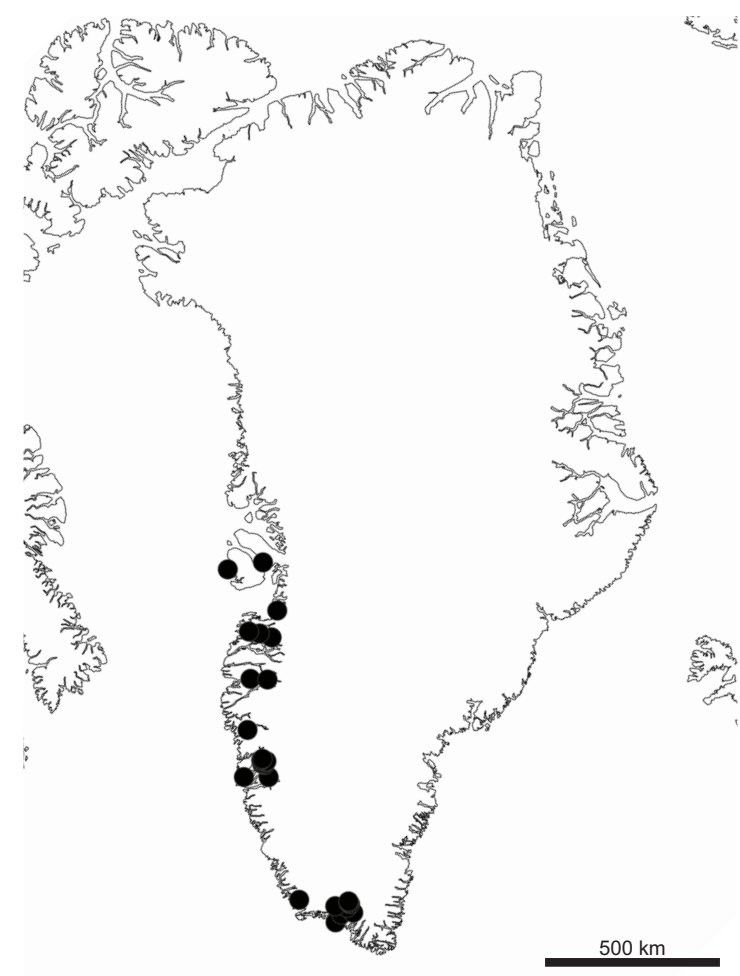

Fig. 14. Distribution of Melanohalea septentrionalis in Greenland.

Montanelia Disjuncta (Erichsen) Divakar, A. Crespo, Wedin \& Essl. (Fig. 15)

Thallus foliose, appressed to occasionally subpulvinate, moderately to loosely adnate, up to $6(-10) \mathrm{cm}$ in diameter. Lobes $(0.4-) 0.8-1.5(-3)$ $\mathrm{mm}$ broad, flat to slightly convex or concave, short and rounded to somewhat elongate, often distinctly flabellate at the end, usually contiguous or becoming imbricate. Upper surface dark olive-brown to blackish, infrequently paler olive- to red-brown, smooth or occasionally irregularly foveolate near the lobe-ends, inward smooth to variously rugulose and/or warted, especially on larger thalli, frequently shiny, especially near the periphery, only occasionally dull throughout, very rarely lightly pruinose; pseudocyphellate, the pseudocyphellae small and very obscure to frequently quite distinct, 
submarginal on the lobes; sorediate, the soralia laminal and submarginal, arising in part from the pseudocyphellae, punctiform to capitate or sometimes short stipitate, sometimes eroded and crateriform, remaining discrete or becoming confluent in older parts, soredia dark gray to black (soralia appearing pale sometimes when abraded or eroded), granular to isidioid. Lower surface very dark brown to black, flat to weakly channeled, smooth to rugulose, dull or slightly shiny in part; moderately rhizinate, the rhizines concolorous with the lower surface. Apothecia infrequent, laminal, concave or flattening, up to $3(-5.5) \mathrm{mm}$ in diameter, sessile or very short stipitate, the margin usually partly to completely sorediate, occasionally remaining entire but then usually rugose and pseudocyphellate; ascospores 8, ellipsoid, 9-12.5×5-7 um; Pycnidia rare, laminal, immersed; conidia $6-7.5 \times 1 \mu \mathrm{m}$, acicular to almost fusiform.

Thallus spot tests: cortex $\mathrm{K}-$, medulla $\mathrm{P}-, \mathrm{K}-$ or rarely $\mathrm{K}+$ dingy, $\mathrm{C}-, \mathrm{KC}$ - or very rarely $\mathrm{KC}+$ faint dingy rose. Lichen substances: perlatolic acid $(+++)$ and stenosporic acid $(+++)$, occasionally with small amounts of unknown substances.

Substrate \& ecology: grows on siliceous and basaltic rocks, including those influenced by guano and other nutritient materials.

Distribution: widely distributed in Greenland; it is more or less common in all parts of Greenland, except so far it is not known from the north coast (Dahl, 1950; Hansen, 1971; Hansen, 1971b, 1999; Alstrup et al. 2000).

Discussion: In Greenland, this species is most likely to be confused with the similar sorediate species $M$ tominii, a species distinguished by its usually larger dimensions, the presence of laminal rather than submarginal pseudocyphellae, and the $\mathrm{C}+$ rose-red reaction in the medulla. The smaller, darker forms of $M$. disjuncta present little difficulty for determination, but there is a larger, paler form which can appear very similar to $M$. tominii, with the only easily discernible morphological difference being the submarginal rather than laminal pseudocyphellae. Such specimens should be carefully spot tested in the medulla for certain determination and this works best on younger thallus parts. Freshly exposed medulla should be used when testing for the $\mathrm{C}+$ reaction of $M$. tominii, since long exposed

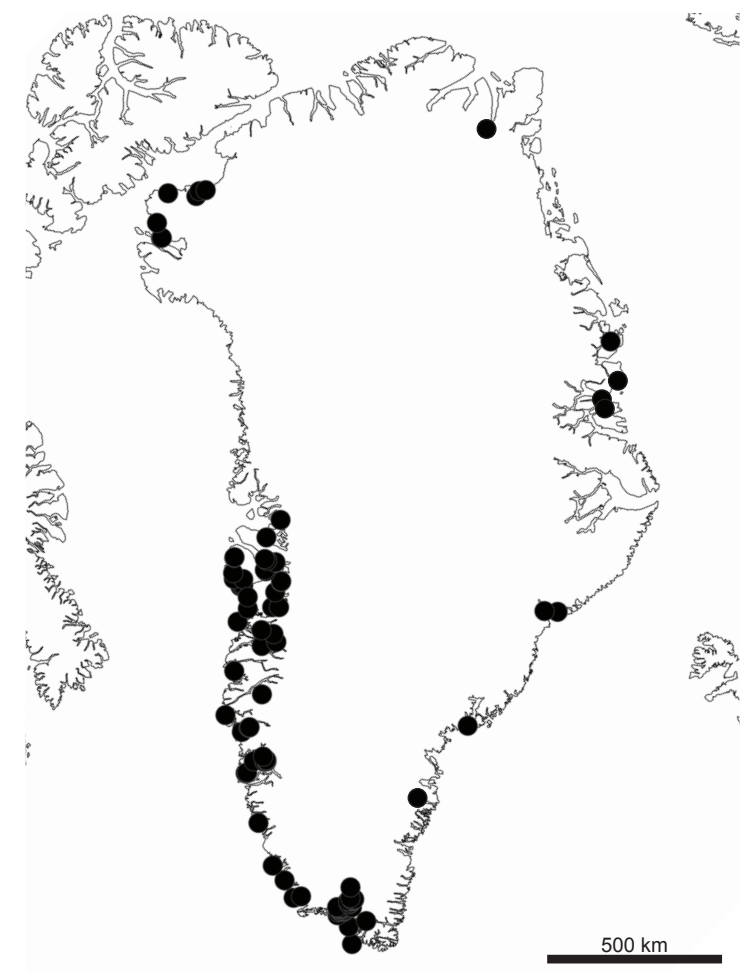

Fig. 15. Distribution of Montanelia disjuncta in Greenland.

medulla in old wounds often will fail to react (a likely cause of many of the misdeterminations seen in herbarium specimens).

This species was also long confused with $M$. sorediata, a less frequent sorediate species in Greenland. That species is readily distinguished from $M$. disjuncta by its lack of pseudocyphellae (which are often quite obscure in $M$. disjuncta too), and the usually very discrete soralia, located primarily on the ends of short, lateral lobes and sometimes the main lobes (Esslinger, 1977).

Esorediate thalli (common in some areas of the far north like Greenland) are sometimes misidentified as $M$. stygia, easily distinguished by its tough, cartilaginous cortex, which must be sliced with a sharp razor, as opposed to the easily shattered cortex of $M$. disjuncta.

Selected specimens examined (from a total of 182): Qeqertarssuatsiaat $\left(63^{\circ} 06^{\prime} \mathrm{N}, 50^{\circ} 40^{\prime} \mathrm{W}\right), 2$ Aug 1993, E. S. Hansen 931249 (C). Qeqertarsuaq $\left(69^{\circ} 15^{\prime} \mathrm{N}, 53^{\circ}\right.$ 32'W), 11 Aug 1996, E. S. Hansen 96426 (C). Siorapaluk $\left(77^{\circ} 47^{\prime} \mathrm{N}, 70^{\circ} 29^{\prime} \mathrm{W}\right), 27$ Jul 2009, E. S. Hansen $93323(\mathrm{C})$. Sødalen $\left(68^{\circ} 12^{\prime} \mathrm{N}, 31^{\circ} 23^{\prime} \mathrm{W}\right)$, alt. $250 \mathrm{~m}$, 
26 Jul 1971, E. S. Hansen 71795 (C). Zackenberg $\left(74^{\circ} 28^{\prime} \mathrm{N}, 20^{\circ} 18^{\prime} \mathrm{W}\right), 8$ Aug 1994, E. S. Hansen 94486 (C).

Montanelia PANNIFormis (Nyl.) Divakar, A. Crespo, Wedin \& Essl. (Fig. 16)

Thallus foliose, appressed to pulvinate, usually more or less panniform, moderately to loosely adnate, up to $7(-10) \mathrm{cm}$ in diameter but sometimes coalescing into larger patches. Lobes (0.3-)0.5-1(-1.5) $\mathrm{mm}$ broad, more or less flat, short and rounded to more often somewhat elongate, discrete to more or less imbricate. Upper surface olive-brown to reddish-brown or dark brown, smooth to weakly foveolate at the periphery, inward essentially the same but usually hidden by numerous small and imbricate lobules, dull or somewhat shiny, occasionally lightly pruinose; without soredia or true isidia, the peripheral lobes soon developing small, more or less spherical to clavate isidioid lobules on top, inward these growing more or less prostrate and often developing into dorsiventral, imbricate lobules which are short to long and finger-like, simple or branched, $0.1-0.5 \mathrm{~mm}$ broad; without pseudocyphellae on the primary lobes, but occasionally present (but very obscure) near the ends of the lobules. Lower surface black, paler at the periphery, flat and smooth to irregularly wrinkled or plicate, dull or slightly shiny; moderately to somewhat sparsely rhizinate, the rhizines concolorous with the lower surface. Apothecia uncommon, laminal, flat to somewhat concave, up to $3 \mathrm{~mm}$ in diameter, sessile, the margin at first entire, very soon papillate to tuberculate or becoming lobulate; ascospores 8, ellipsoid, 9-1 1.5×4.5-7 $\mu \mathrm{m}$. Pycnidia common, laminal, immersed; conidia (4-)5-7 $\times$ ca. $1 \mu \mathrm{m}$, more or less cylindrical to weakly fusiform or acicular.

Thallus spot tests: cortex $\mathrm{K}-$; medulla $\mathrm{P}-, \mathrm{K}-, \mathrm{C}-$, $\mathrm{KC}-$ or very rarely $\mathrm{KC}+$ faint dingy rose. Lichen substances: perlatolic acid $(+++)$ and stenosporic acid $(+++)$, occasionally with trace unknowns.

Substrate \& ecology: grows preferably on more or less moist, vertical and overhanging, siliceous rocks with different exposures.

Distribution: widely distributed in South West and Central West Greenland (Dahl, 1950; Hansen, 1962), and collected by V. Alstrup at Qaanaaq in North West Greenland; apparently lacking in East Greenland.

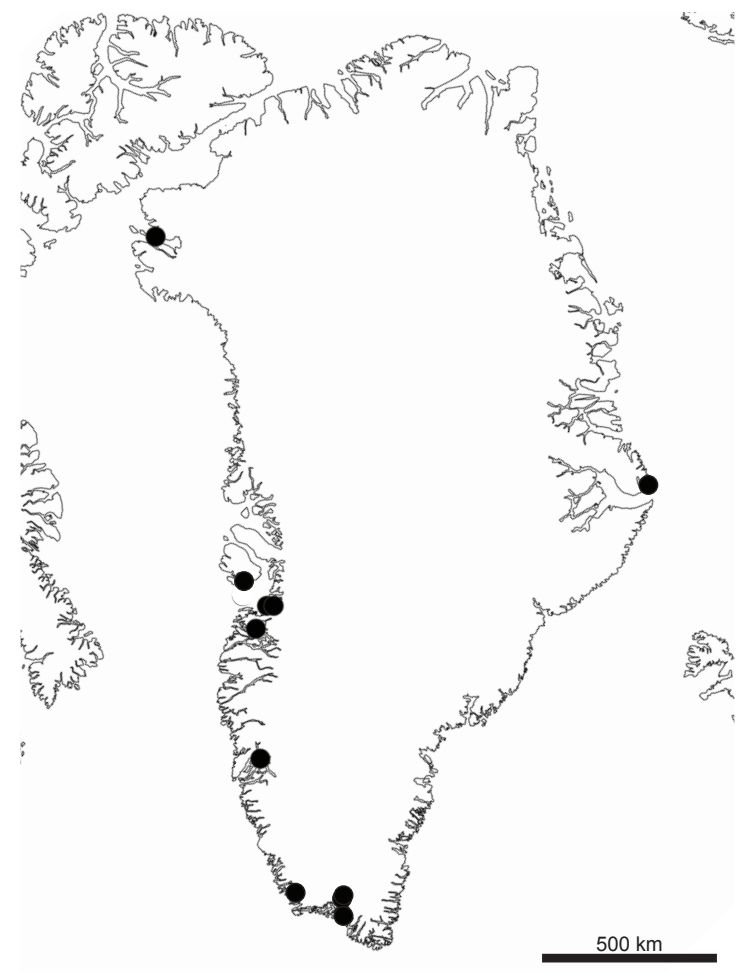

Fig. 16. Distribution of Montanelia panniformis in Greenland.

Discussion: Typical specimens of M. panniformis with the numerous imbricate lobules covering all or most of the thallus are distinctive and seldom misidentified. However, small or poorly developed specimens with only under-developed, isidioid lobules, can sometimes be confused with several isidiate species of Melanohalea, notably $M$. exasperatula and, especially, M. infumata which shares the same substrate. Development of the surface structures as isidia in those two species is usually much more regular and the isidia are not dorsiventral. When doubt exists, M. panniformis can be distinguished by TLC, since both Melanohalea species lack medullary substances.

Occasionally, specimens of unrelated Allantoparmelia almquistii (Vainio) Essl. develop numerous long, imbricate lobules and have been misidentified as $M$. panniformis. They are easily distinguished by the total lack of rhizines on the mostly pale lower surface and the $\mathrm{C}+$ rose-red medullary reaction (olivetoric acid). 
Specimens examined (from a total of 22): Godthåbsfjord, Ilulialik, Igdlorssuit $\left(64^{\circ} 47^{\prime} \mathrm{N}, 50^{\circ} 36^{\prime} \mathrm{W}\right)$, alt. 75 m, 27. Jul 1976, V. Alstrup 76555 (C). Arfersiorfik Fjord, Agpaqarfik $\left(68^{\circ} 11^{\prime} \mathrm{N}, 51^{\circ} 46^{\prime} \mathrm{W}\right)$, alt. 30 m, 29 Sep 1951, P. Gelting 16289c (C). Igdluko (68 49'N, $\left.51^{\circ} 11^{\prime} \mathrm{W}\right), 16$ Sep 1952, P. Gelting 19058d (C). Kangersuneq $\left(68^{\circ} 50^{\prime} \mathrm{N}, 50^{\circ} 43^{\prime} \mathrm{W}\right)$, alt. $25 \mathrm{~m}, 15$ Aug 1958, $K$. Hansen 1515 (C). Qaanaaq $\left(77^{\circ} 28^{\prime} \mathrm{N}, 69^{\circ} 17^{\prime} \mathrm{W}\right)$, alt. 125 m, 7 Aug 1991, V. Alstrup 917516 (C).

Montanelia sorediata (Ach.) Divakar, A. Crespo, Wedin \& Essl. (Fig. 17)

Thallus foliose, appressed, moderately to rather loosely adnate, up to $4(-6) \mathrm{cm}$ in diameter. Lobes (0.2-)0.5-1.5(-3) $\mathrm{mm}$ broad, usually flat or occasionally slightly concave, somewhat elongate and linear, usually discrete to loosely imbricate. Upper surface generally olive-brown to graybrown, occasionally darkening to almost black, smooth or sometimes reticulately ridged and pitted, especially on the lobe-ends, usually dull but occasionally rather shiny, especially on the lobe-ends, rarely lightly pruinose; sorediate, the soredia terminal on short lateral branches or sometimes on the primary lobes, arising by gradual dissolution of the cortex, more or less capitate, sparse to numerous but remaining discrete, soredia brownish-gray or occasionally darker (appearing paler when abraded), granular to isidioid; without pseudocyphellae. Lower surface very dark brown or black, frequently paler at the periphery; more or less flat, smooth to occasionally weakly rugose or plicate, dull to slightly shiny; moderately rhizinate, the rhizines concolorous with the lower surface. Apothecia rare, laminal, concave to flattening, to $2.5 \mathrm{~mm}$ in diameter, sessile or short stipitate, the margin entire or weakly and irregularly crenulate; ascospores 8, ellipsoid to somewhat ovoid, 9-11 x4.5-6 $\mu \mathrm{m}$. Pycnidia not seen.

Thallus spot tests: cortex $\mathrm{K}-$; medulla $\mathrm{P}-$, $\mathrm{K}-$, $\mathrm{C}-, \mathrm{KC}-$ or very rarely faint dingy rose. Lichen substances: perlatolic acid $(+++)$ and stenosporic acid $(+++)$, occasionally with small amounts of unknown substances.

Substrate \& ecology: occurs on siliceous and basaltic rocks and more rarely on bark of Alnus and Salix (Dahl, 1950; Alstrup, 1982).

Distribution: known from South West Greenland, where it grows on rocks and bark of different shrubs (Dahl, 1950; Alstrup, 1982), Central
West, South East and Central East Greenland (Lynge \& Scholander, 1932; Dahl et al., 1937; Hansen, 1982), occurring exclusively on rocks in the three last mentioned areas.

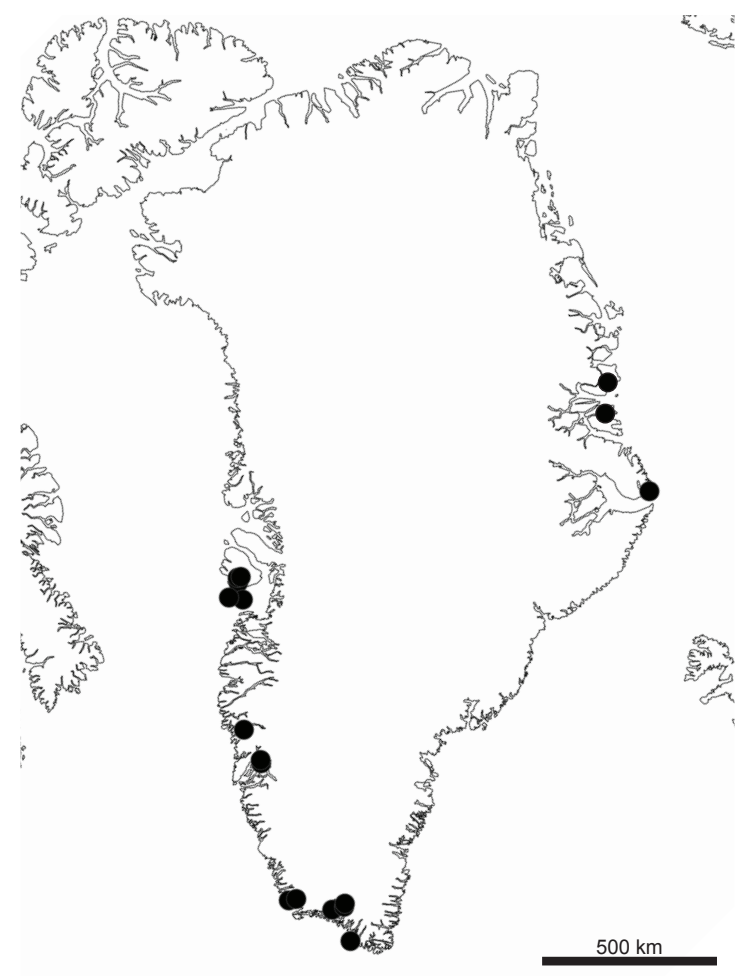

Fig. 17. Distribution of Montanelia sorediata in Greenland.

Discussion: Montanelia sorediata is less common in Greenland than closely related M. disjuncta. The existence of these two species within the sorediate members of this small group has been understood at least since the papers by Lynge (1928) and Lynge and Scholander (1932), the latter one dealing with Greenland lichens. Montanelia sorediata differs from $M$. disjuncta by its lack of pseudocyphellae and by having terminal soralia, primarily on the ends of small lateral lobes. It's also a somewhat smaller and more delicate species, with generally thinner, narrower, and more discrete lobes. The other sorediate species in the group, $M$. tominii, is easily distinguished by its $\mathrm{C}+$ rose-red medullary reaction. 
Selected specimens examined (from a total of 32): Qagssiarssuk $\left(61^{\circ} 09^{\prime} \mathrm{N}, 4^{\circ} 33^{\prime} \mathrm{W}\right), 17 \mathrm{Jul} 1980, E$. S. Hansen $80203(\mathrm{C})$. Grønnedal $\left(61^{\circ} 14^{\prime} \mathrm{N}, 48^{\circ} 05^{\prime} \mathrm{W}\right)$, alt. 25 m, 11 Jul 1946, M. Skytte Christiansen 1209 (C). Qeqertarsuaq $\left(69^{\circ} 15^{\prime} \mathrm{N}, 5^{\circ} 31^{\prime} \mathrm{W}\right), 24$ Sep 1953 , P. Gelting 21098 (C). Ittoqqortoormiit $\left(70^{\circ} 29^{\prime} \mathrm{N}\right.$, $\left.21^{\circ} 58^{\prime} \mathrm{W}\right), 24$ Jul 1987, E. S. Hansen 87802 (C). Myggbukta $\left(73^{\circ} 31^{\prime} \mathrm{N}, 21^{\circ} 37^{\prime} \mathrm{W}\right)$, alt. $10 \mathrm{~m}, 1$ Aug 1930, $P$. F. Scholander (C).

Montanelia tominiI (Oxner) Divakar, A. Crespo, Wedin \& Essl. (Fig. 18)

Thallus foliose, appressed to pulvinate or subpanniform, moderately to loosely adnate, up to $10(-14) \mathrm{cm}$ in diameter. Lobes $(0.5-) 1-3(-4) \mathrm{mm}$ broad, flat to weakly convex, short and rounded or flabellate to somewhat elongate or occasionally linear-elongate, more or less discrete to imbricate. Upper surface pale olive-brown to yellowish-brown or reddish-brown, dark brown or blackening, sometimes paler at the periphery, smooth to weakly foveolate near the lobe-ends, inward smooth to rather strongly fissured and/ or rugose, dull throughout or rather shiny, especially near the periphery; pseudocyphellate, the pseudocyphellae very distinct to occasionally rather obscure or rarely almost lacking, laminal, darkened to pale or more or less concolorous with the upper surface; sorediate, but highly variable in number of soralia produced (totally esorediate material is not rare), the soralia laminal and marginal, punctiform to capitate, arising in part from the pseudocyphellae, soredia pale brown to rather dark brown or occasionally grayblack, granular to weakly isidioid. Lower surface dark brown to black, paler on the lobe-ends, more or less flat, smooth to somewhat plicate or rugose, dull to slightly shiny; moderately rhizinate, the rhizines more or less concolorous with the lower surface. Apothecia: frequent, laminal, concave to flattening or irregular, up to $6 \mathrm{~mm}$ in diameter, sessile to short stipitate, the margin often becoming sorediate, occasionally remaining entire to weakly crenate and pseudocyphellate; ascospores 8, ellipsoid, 8.5-11×4.5-7 $\mu \mathrm{m}$. Pycnidia common, laminal, immersed; conidia 5-7 $\times$ ca. $1 \mu \mathrm{m}$, cylindric to weakly fusiform or weakly bifusiform.

Thallus reactions: cortex $\mathrm{K}-$, medulla $\mathrm{P}-, \mathrm{K}-$, $\mathrm{C}+$ rose or rose-red, $\mathrm{KC}+$ rose-red. Lichen substances: gyrophoric acid $(+++)$, ovoic acid (+ or $++)$, unknown WG-2 (trace or + ).
Substrate \& Ecology: on exposed siliceous and basaltic rocks influenced by nutrient dust, loess or guano from ravens and other birds (Dahl, 1950; Hansen, 1971; Hansen, 1991, 2000), sometimes on mosses over such rocks.

Distribution: common in South West and Central West Greenland, particularly in continental areas, for example, the head of Kangerlussuaq, where it occurs on rocks and boulders influenced by loess and guano. The species occurs more scattered in South East and Central East Greenland (Dahl et al., 1937; Hansen, 1982).

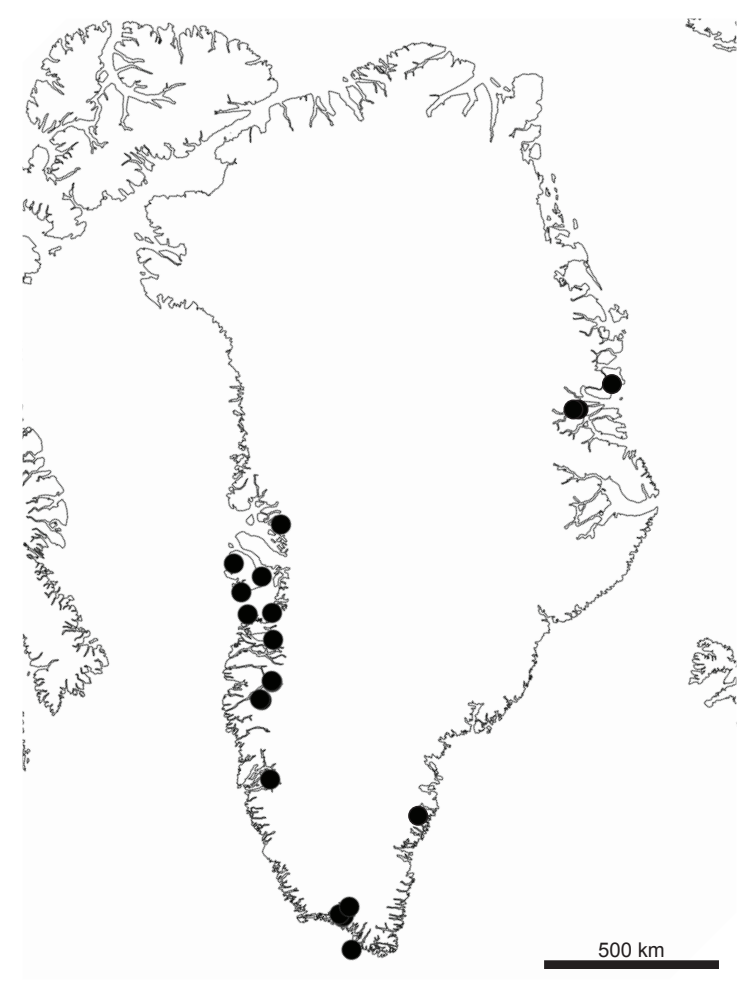

Fig. 18. Distribution of Montanelia tominii in Greenland.

Discussion: In the genus Montanelia, this species is easily distinguished from all the others by its laminal pseudocyphellae (rarely obscure) and the $\mathrm{C}+$ rose-red reaction in the medulla. When using this spot test, care should be taken to test freshly exposed medulla on the younger thallus parts. Medulla from old thallus parts often gives only a relatively weak (or no) reaction, and me- 
dulla in old wounds which has been exposed for a period of time often gives little or no response at all, even in younger thallus parts.

Among the other brown parmelioid species in Greenland, two rare species, Melanelixia glabratula and $M$. subaurifera, also react $\mathrm{C}+$ red in the medulla (lecanoric acid), but both are isidiate species.

Early reports of Parmelia isidiotyla ( $=$ Xanthoparmelia verruculifera) from Greenland were based on material of this species.

Selected specimens examined (from a total of 53): Kangerlussuaq $\left(67^{\circ} 02^{\prime} \mathrm{N}, 50^{\circ} 40^{\prime} \mathrm{W}\right), 28 \mathrm{Jul} 1998, E$. S. Hansen 93221 (C). Igdluko $\left(68^{\circ} 49^{\prime} \mathrm{N}, 51^{\circ} 11^{\prime} \mathrm{W}\right), 16$ Sep 1952, P. Gelting 19067 (C). Qaumarujuk $\left(71^{\circ} 09^{\prime} \mathrm{N}\right.$, $51^{\circ} 14^{\prime}$ W), 22 Jul 1989, E. S. Hansen 89423 (C). Eqalungmiut, Dronning Maries Dal $\left(63^{\circ} 28^{\prime} \mathrm{N}, 41^{\circ} 55^{\prime} \mathrm{W}\right)$, 25 Jul 1932, P. F. Scholander (C). Moskusoksefjord $\left(73^{\circ} 35^{\prime} \mathrm{N}, 22^{\circ} 25^{\prime} \mathrm{W}\right), 19$ Aug. 1929, B. Lynge (C).

\section{ACKNOWLEDGEMENTS}

Thanks are due to the herbarium staff at UPS for arranging a small loan of comparison specimens from the Nordic countries. The molecular portion of this study was funded by The National Science Foundation (DEB-0949147).

\section{REFERENCES}

Ahti, T. 1966. Parmelia olivacea and the allied nonisidiate and non-sorediate corticolous lichens in the Northern Hemisphere. Acta Botanica Fennica 70: $1-68$.

Alstrup, V. 1977. Cryptogams on imported timber in West Greenland. Lichenologist 9: 113-117. http:/ / dx.doi.org/10.1017/S002428297700019X

Alstrup, V. 1982. The epiphytic lichens of Greenland. The Bryologist 85(1): 64-73. http://dx.doi. org/ 10.2307/3243141

Alstrup, V., Hansen, E. S. \& Daniels, F. 2000. Lichenized, lichenicolous and other fungi from North and North-East Greenland. Folia Cryptogamica Estonica 37: 1-20.

Blanco, O., Crespo, A., Divakar, P. K., Esslinger, T. L., Hawksworth, D. L. \& Lumbsch, H. T. 2004. Melanelixia and Melanohalea, two new genera segregated from Melanelia (Parmeliaceae) based on molecular and morphological data. Mycological Research 108(8): 873-884. http://dx.doi. org/ 10.1017/S0953756204000723

Branth, J. S. D. \& Grønlund, C. 1888. Grønlands Lichen-Flora. Meddelelser om Grønland 3: 449-513.

Culberson, C. F. 1972. Improved conditions and new data for the identification of lichen products by a standardized thin-layer chromatographic method.
Journal of Chromatography 72: 113-125. http:/ / dx.doi.org/10.1016/0021-9673(72)80013-X

Culberson, C. F. 1974. Conditions for the use of Merck silica gel 60 F-254 plates in the standardized thin-layer chromatographic technique for lichen products. Journal of Chromatography 97: 107-108. http://dx.doi.org/10.1016/S00219673(01)97595-8

Culberson, C. F. \& Kristinsson, H. 1970. A standardized method for the identification of lichen products. Journal of Chromatography 46: 85-93. http://dx.doi.org/10.1016/S00219673(00)83967-9

Dahl, E. 1950. Studies in the macrolichen flora of southwest Greenland. Meddelelser om Grønland 150(2): 1-176.

Dahl, E.; Lynge, B. \& Scholander, P. F. 1937. Lichens from Southeast Greenland collected chiefly by Dr. P. F. Scholander in 1932 during the Norwegian expedition in the S/S "Polaris". Skrifter om Svalbard og Ishavet 70: 1-76.

Divakar, P. K., Del-Prado, R, Lumbsch, H. T., Wedin, M., Esslinger, T. L., Leavitt, S. D. \& Crespo, A. 2012. Diversification of the newly recognized lichen-forming fungal lineage Montanelia (Parmeliaceae, Ascomycota) and its relation to key geological and climatic events. American Journal of Botany 99(12): 2014-2026. http://dx.doi. org/10.3732/ajb. 1200258

Esslinger, T. L. 1977. A chemosystematic revision of the brown Parmeliae. Journal of the Hattori Botanical Laboratory 42: 1-211.

Esslinger, T. L. 1978. A new status for the brown Parmeliae. Mycotaxon 7: 45-54.

Esslinger, T. L. 2002. Melanelia. In: Nash III, T. H., Ryan, B. D., Gries, C. \& Bungartz, F. Lichen Flora of the Greater Sonoran Desert Region, vol. I. Tempe, Arizona, Lichens Unlimited, Arizona State University, pp. 274-286.

Ferguson, J. 1964. Geology of the Ilimaussaq alkaline intrusion, South Greenland. Gronlands Geologiske undersøgelse 39: 1-82.

Gelting, P. 1956. Parmelia subaurifera Nyl. and P. fraudans (Nyl.) Nyl. in Greenland. Friesia 5: 240-246.

Fries, T. M. 1860. Lichenes Arctoi Europae Groenlandiaeque hactenus cogniti. Ex Actis Reg. Soc. Scientiarum Ups., Seriei III, Vol. III, Upsaliae. 298 pp.

Hansen, E. S. 1978a. A comparison between the lichen flora of coastal and inland areas in the Julianehåb district. Meddelelser om Grønland 204(3): 1-31.

Hansen, E. S. 1978b. Notes on occurrence and distribution of lichens in South East Greenland. Meddelelser om Grønland 204(4): 1-71.

Hansen, E. S. 1982. Lichens from Central East Greenland. Meddelelser om Grønland - Bioscience 9: 1-33.

Hansen, E. S. 1991. The lichen flora near a leadzinc mine at Maarmorilik in West Greenland. Lichenologist 23(4): 381-391. 
Hansen, E. S. 1995a. Greenland Lichens. Atuagkat, Rhodos and Danish Polar Center. Copenhagen. 124 pp.

Hansen, E. S. 1995b. The lichen flora near Ittoqqortoormiit/Scoresbysund in Central East Greenland. Herzogia 11: 197-206.

Hansen, E. S. 2000. A contribution to the lichen flora of the Kangerlussuaq area, West Greenland. Cryptogamie, Mycologie 21(1): 53-59. http://dx.doi. org/10.1016/S0181-1584(00)00104-4

Hansen, E. S. 2001. Lichens and lichenicolous fungi from Washington Land, western North Greenland. Folia Cryptogamica Estonica 38: 1-8.

Hansen, E. S. 2002. Lichens from Inglefield Land, NW Greenland. Willdenowia 32: 105-125.

Hansen, E. S. 2009. Lichens from Johannes V. Jensen Land, the northernmost arctic land area. Willdenowia 39: 179-186. http://dx.doi.org/10.3372/ wi.39.39119

Hansen, E. S. 2010. A review of lichen growth and applied lichenometry in southwest and southeast Greenland. Geografiska Annaler 92A(1): 65-79. http://dx.doi.org/10.1111/j.14680459.2010.00378.x

Hansen, E. S. 2011. Lichens from Qaanaaq and Siorapaluk, North Greenland. Folia Cryptogamica Estonica 48: 5-11.

Hansen, E. S. 2012. Lichens from one locality at Frederikshåbs Isblink and two localities in the Fiskenæsset area, South West Greenland. Folia Cryptogamica Estonica 49: 23-30.

Hansen, K. 1971. Lichens in south Greenland. Distribution and ecology. Meddelelser om Grønland 178: $1-84$.

Kärnefelt, I. 1979. The brown fruticose species of Cetraria. Opera Botanica 46: 1-150.

Kärnefelt, I., Mattsson, J.-E. \& Thell, A. 1993. The lichen genera Arctocetraria, Cetraria, and Cetrariella (Parmeliaceae) and their presumed evolutionary affinities. The Bryologist 96(3): 394-404. http://dx.doi.org/10.2307/3243869

Leavitt, S. D., Esslinger, T. L., Divakar, P. K. \& Lumbsch, H. T. 2012a. Miocene divergence, phenotypically cryptic lineages, and contrasting distribution patterns in common lichen-forming fungi (Ascomycota: Parmeliaceae). Biological Journal of the Linnean Society 107(4): 920-937. http:/ / dx.doi.org/10.1111/j.1095-8312.2012.01978.x

Leavitt, S. D., Esslinger, T. L., Divakar, P. K. \& Lumbsch, H. T. 2012b. Miocene and Pliocene dominated diversification of the lichen-forming fungal genus Melanohalea (Parmeliaceae, Ascomycota) and Pleistocene population expansion. BMC Evolutionary Biology 12: 176. http:/ / dx.doi. org/10.1186/1471-2148-12-176

Leavitt, S. D., Esslinger, T. L., Hansen, E. S., Divakar, P. K., Crespo, A., Loomis, B. F. \& Lumbsch, H. T. 2014. DNA barcoding of brown Parmeliae (Parmeliaceae) species: a molecular approach for accurate specimen identification, emphasizing species in Greenland. Organisms, Diversity \& Evolution 14: 11-20. http:/ /dx.doi.org/10.1007/ s13127-013-0147-1

Leavitt, S. D., Esslinger, T. L., Spribille, T., Divakar, P. K. \& Lumbsch, H. T. 2013. Multilocus phylogeny of the lichen-forming fungal genus Melanohalea (Parmeliaceae, Ascomycota): Insights on diversity, distributions, and a comparison of species tree and concatenated topologies. Molecular Phylogenetics and Evolution 66(1): 138-152. http:// dx.doi.org/10.1016/j.ympev.2012.09.013

Lynge, B. 1912. Neue flechten aus Norwegen. Bergens Museum Årbok 1912(10): 1-10.

Lynge, B. 1928. Lichens from Novaya Zemlya. Rep. Sci. Results Norweg. Exped. Novaya Zemlya 1921, No. 43: 1-299, pl. 1-13.

Lynge, B. 1937. Lichens from West Greenland. Collected chiefly by Th. M. Fries. Meddelelser om Grønland 118(8): 1-225.

Lynge, B. \& Scholander, P. F. 1932. Lichens from North East Greenland collected on the Norwegian Scientific Expeditions in 1929 and 1930. I. Skrifter om Svalbard og Ishavet 41: 1-116, pl. 1-7.

Thell, A., Feuerer, T., Kärnefelt, I., Myllys, L. \& Stenroos, S. 2004. Monophyletic groups within the Parmeliaceae identified by ITS rDNA, ß-tubulin and GAPDH sequences. Mycological Progress 3(4): 297-314. http://dx.doi.org/10.1007/s1 1557006-0100-1

Thell, A. \& Kärnefelt, I. 2011. Cetrariella. In: Thell, A. \& Moberg, R. (eds.). Nordic Lichen Flora 4, pp. 43-45.

Thomson, J. W. 1984. American Arctic Lichens 1. The Macrolichens. Columbia University Press, New York. 504 pp.

Truong, C., Naciri, Y. \& Clerc, P. 2009. Multivariate analysis of anatomical characters confirms the differentiation of two morphologically close species, Melanohalea olivacea (L.) O. Blanco et al. and $M$. septentrionalis (Lynge) $\mathrm{O}$. Blanco et al. Lichenologist 41(6): 649-661. http://dx.doi. org/ 10.1017/S0024282909990260 